EUROPEAN UNIVERSITY INSTITUTE, FLORENCE

DEPARTMENT OF LAW

EUI Working Paper LAW No. 2005/11

The Challenge of Governance in Regional Integration Key Experiences from Europe

JACQUES ZILLER

BADIA FIESOLANA, SAN DOMENICO (FI) 
All rights reserved.

No part of this paper may be reproduced in any form without permission of the author(s)

(C) 2005 Jacques Ziller \& IADB

Published in Italy in June 2005

European University Institute

Badia Fiesolana

I - 50016 San Domenico (FI)

Italy

www.iue.it 


\title{
The Challenge of Governance in Regional Integration Key Experiences from Europe
}

\author{
Jacques Ziller \\ To be also published as Working paper \\ By the Inter-American Development Bank \\ http://www.iadb.org
}




\section{List of abbreviations}

$\mathrm{ACP}$

CFI

EEA

$\mathrm{EC}$

ECB

ECJ

EEC

EFTA

EMU

ESCS

EU

ICJ

PCIJ

SECB
Associated countries of Africa, the Caribbean and the Pacific Ocean

Court of First Instance

European Economic Area

European Community

European Central Bank

European Court of Justice

European Economic Community

European Free Trade Area

European Monetary Union

European Coal and Steel Community

European Union

International Court of Justice

Permanent Court of International Justice

System of European Central Banks 
Introduction $\quad 5$

1. Regional Integration as a Dynamic Process 9

1.1. Growing membership and scope,

from the ECSC of Six in 1951 to the EU of the Twenty Five in 2004

1.1.1. Deepening integration 11

1.1.2. Enlarging the European Communities and Union 13

1.2. Why enlargement did not lead to a reduction of the scope of integration 19

1.2.1. Transition periods 19

1.2.2. The acquis communautaire 21

1.2.3. Differentiation and asymmetries between EC/EU member states 22

1.2.4. Differentiation in the scope of integration 26

1.2.5. Diversity and common goals 30

1.3. Conclusions to section $1 \quad 31$

2. The 'Community method': the European Solution to Regional Integration 33

2.1. Pooling of sovereignties/powers/competences 35

2.2. The 'institutional triangle $\quad 37$

2.2.1. Three institutions $\quad 37$

2.2.2. A joint decision-making procedure $\quad 39$

2.3. Functionalism and incremental evolution $\quad 42$

2.4. Integration through law 44

2.4.1. Directly applicable law $\quad 44$

2.4.2. Enforcement mechanisms not relying on reciprocity 46

2.4.3. A network of Courts $\quad 48$

2.4.4. Legal professions as stakeholders of integration 50

2.5. Community method v. intergovernmental method? 52

3. Regional Integration as a 'Multilevel' issue $\quad 55$

3.1. Implementation and multilevel governance $\quad 56$

3.2. Multilevel governance and legitimacy $\quad 57$

3.3. Multilevel governance and institutional reform 58

4. Key Issues and Proposed Solutions for European Governance

at the time of Eastern enlargement and of the Constitution for Europe $\quad 61$

4.1. Keeping an efficient and democratic system for decision making

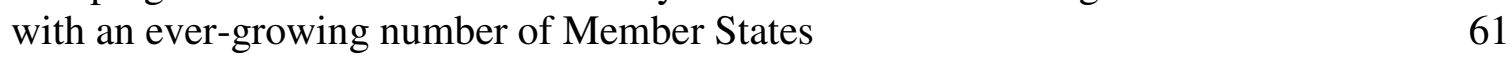

4.2. Enhancing co-ordination through alternatives to the Community method 66

4.2.1. The 'Open Method of Coordination 66

$\begin{array}{ll}\text { 4.2.2. } & \text { European Agencies } \\ \end{array}$

4.3. Differentiating integration according to policy fields $\quad 69$

4.4. Addressing the management deficit of the EC/EU system in a context of continuous enlargement and deepening of European integration $\quad 71$

List of Tables $\quad 74$

$\begin{array}{ll}\text { Selected Bibliography } & 75\end{array}$ 
This paper addresses the issue of the relevance for Latin America and the Caribbean of European experience with the governance of regional integration. It focuses on the global governance of the European Communities (EC) and European Union (EU) ${ }^{1}$ in the light of the constitutional process which the EC/EU is undergoing in the present years and of the management deficit in regional integration which has been experienced by the EC/EU, especially since about two decades. While those contemporary elements are being considered as decisive in order to understand the present stage of integration of Europe, the governance aspects of the developments which have lead from the first experience of the European Coal and Steel Community (ESCS) in 1950-51 between six countries to the present EC/EU of twenty five countries will be given special attention, as they are indispensable in order to understand how the present stage of integration has been achieved.

Table 1: European Communities (EC) and European Union (EU)

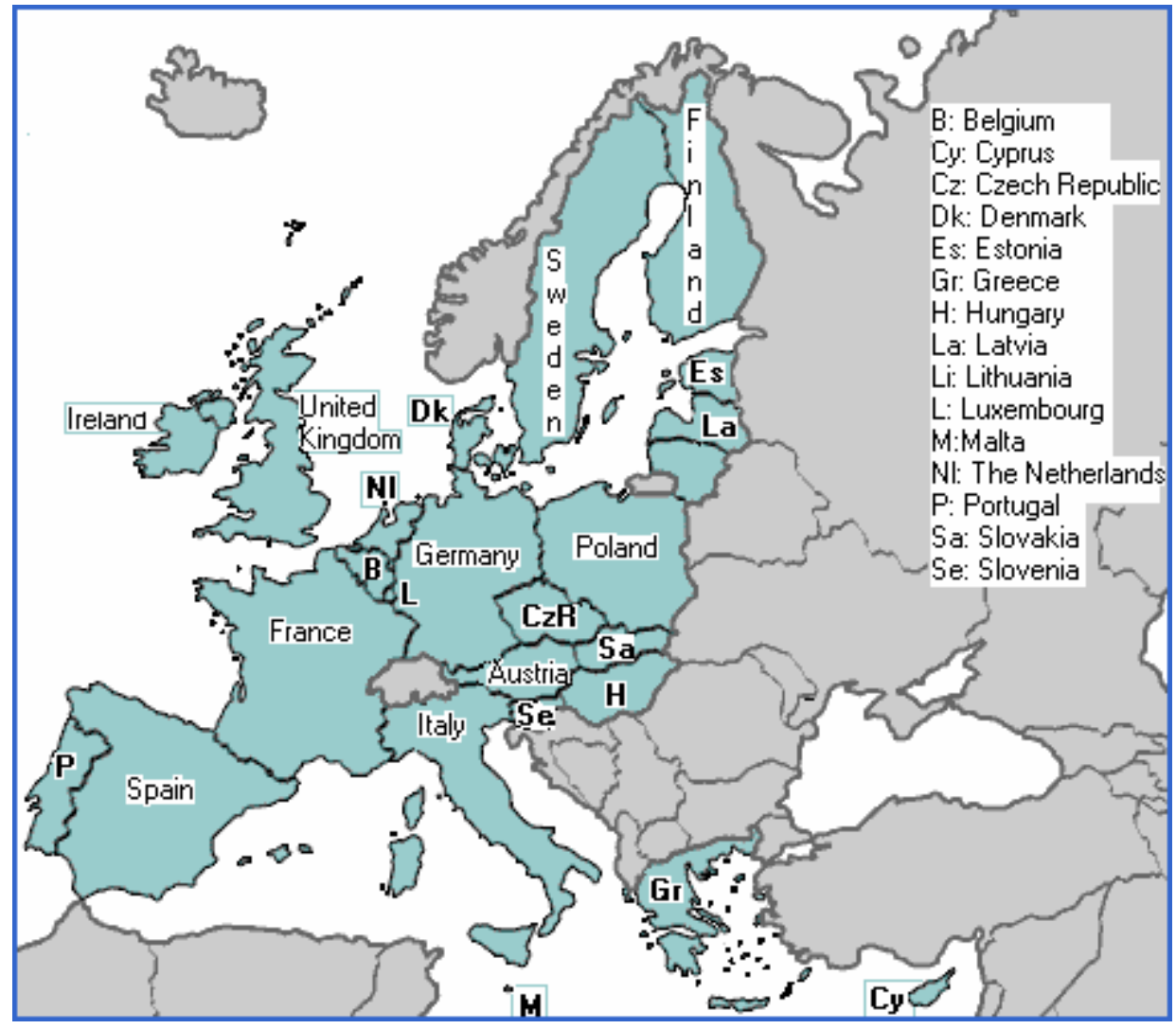

\footnotetext{
${ }^{1}$ The acronym EC/EU will be preferred to a reference to the sole EU whenever this paper relates to the common institutional arrangements. A reference to only the EC or the EU will prevail when the paper relates to fields of
} 
From a geographical and political perspective, the EC and the EU are the same: a regional grouping of at present 25 member states (since 1 may 2004), with a specific set of common institutions (Parliament, Council, Commission, Court of Justice etc.). However the EC and EU are legally distinct in terms of their founding treaties, and more importantly in terms of fields of actions and of decision-making procedures. The field of action of the EC has developed out of economic integration into a set of accompanying policies in the socio-economic field and it has only very recently started to include some aspects related to immigration. The EU's specific fields of action are in politically more salient fields as regards to a classical perception of sovereignty, namely foreign affairs, defence/security, police and justice.

The starting point of this paper is the fact that counsels and experts, or even representatives of donor organisations in international conferences, are too often recommending to developing countries that they follow the example of Europe in order to achieve development by means of regional integration ${ }^{2}$. This type of recommendation is counterproductive or even dangerous when it results into an exercise of institutional engineering, trying to transpose to other continents or regions of the world the organisational and legal arrangements upon which the $\mathrm{EC} / \mathrm{EU}$ is based. The possible relevance of EC/EU institutions and arrangements for other parts of the world can only be assessed by taking into account the specific European environment, in terms of economic, social and administrative development, the historical experiences upon which efforts in regional integration are based, and the culture of the different stakeholders in the process of integration.

Attempts at transposing the EC/EU institutional and legal framework very often overlook the incremental nature of the European process of regional integration. Far from having followed a blueprint, European states have progressively set up their institutions and tools as they were deciding to integrate their markets and further develop common policies in a growing number of areas. Furthermore they have not developed a set of solutions that would be valid once and forever. The treaties of Paris (1951 - establishing the ECSC) and of Rome

\footnotetext{
action which pertain to either the EC or the EU.

${ }^{2}$ The author is referring mainly to personal experience of his own, and of other specialists who have had the opportunity to work on regional integration. This type of experience is not easy to document with written evidence, as more care is usually given to reports, official or even unofficial documents and academic writings than to oral communication. Experience shows however that the latter is far more influential in practice, especially as decision makers have little time to consult long and precise documents.
} 
(1957 - establishing the European Economic Community [EEC $]^{3}$ and the European Community of Atomic Energy [EURATOM]) have set up the basis of the institutional setting which is still that of the EC/EU today. They have been incrementally reformed by the Treaty establishing a single Commission and a single Council (1965) followed a few years later by treaties which have gradually given more budgetary autonomy to the Communities, the Decision to elect the European Parliament directly (1976), the Single European Act (1986), and the Treaties of Maastricht (1992) Amsterdam (1997) and Nice (2001), and now by the Treaty establishing a Constitution for Europe (2004). As far as institutions are concerned, the aim of these reforms was mainly to make them more efficient and to increase their democratic character. Since 1986 their aim has also been to extend the scope of common actions. These numerous treaties which have amended the initial basis for integration and Community action have been trying to solve governance issues, when they reformed the institutions; they have often contributed to create new problems of governance, as happened with every enlargement to new member states, and every deepening of integration due to the increase of the Community ${ }^{4}$ and Union fields of action. A number of governance issues are not settled by the treaties, but depend upon internal arrangements within and between the common institutions, and upon management practices in the European Commission and European agencies, which are being scrutinised and reviewed on a regular basis.

The EC/EU is not only a success story in designing, planning and implementing institutional and procedural arrangements, it is also a story of a number of missed opportunities as well as of muddling through punctuated by a number of crises. Examining both successes and failures in European integration is far more valuable than only explaining what has been set up and how it works.

Understanding the reasons of the choices that have been made, and even more the conditions and environment in which this new regime of regional governance has been set up

\footnotetext{
${ }^{3}$ The EEC has been renamed European Community (EC) - without any adjective - in 1993 because the Treaty of Maastricht broadened its scope with provisions about citizenship.

${ }^{4}$ The powers and fields of action of the European Economic Community (EEC) have been continuously expanded, and it has therefore changed its name to European Community (EC); the powers and fields of action of the two other communities have remained unchanged, until 22 July 2002, when the ECSC came to an end, as foreseen by the treaty which was established for a period of fifty years. The coal and steel sectors fall since then under the general provision of the EC Treaty. EURATOM continues its existence as a separate organization using
} 
in the last five decades, is indispensable in order to asses to what extent European experiences may or may not be relevant to other attempts at regional integration (Section 1). European states have developed an unprecedented method for regional integration, based both on practical experience and on conceptual choices: the 'Community method'. Analysing as well the organisational settings as the conceptual foundations of the Community method should help understanding to what extent it might be transposed in other regional settings and furthermore, to what extent it is possible to take only some elements of the Community institutions and procedures while keeping the coherence that is probably at the roots of its success (Section 2). Focusing on the organisational and legal framework set up at the supranational level would however be misleading, as this would neglect a very important part of the issues and solutions that have to be taken into account in order to make regional integration work. As a matter of fact, taking into account the organisational settings and procedures which have been established within the member states of the EC/EU is as important as studying the EC/EU supranational framework. It allows understanding far better both successes and failures in European regional integration, because regional integration has to be understood as an issue of multilevel governance (Section 3). European regional integration should not be looked at with the idea of merely transposing so-called best practices. Two important changes occurred in 2004. From 15 member states the EC/EU was enlarged to 25; eight of the new member states have been "socialist" countries with a single party system" centralised state economies and hardly any autonomy as to the Soviet Union in foreign relations until the end of the nineteen eighties. The second change was the signature of a new Treaty 'establishing a Constitution for Europe' which will replace the present EC/EU treaties. With these two innovations the European Union faces a growing number of challenges. Some of these challenges are not unknown, but they are becoming for more important. Some other challenges are unprecedented. Even though these new developments are quite unique to Europe, understanding the key issues in the governance of present day EC/EU might be relevant to other regional settings, both by pointing out the specific character of these issues and by showing which methods are being used in order to try and address these challenges (Section 4).

the EC/EU institutions, and this will continue once the Treaty establishing a Constitution for Europe will have replaced the present day EC and EU by a new and single European Union (composed of the same member states). ${ }^{5}$ Even though formally other political parties subsisted in most of these countries after their integration into the Soviet Union's sphere of influence in 1947-48, these were mere satellites of the dominating communist party; 


\section{Regional Integration as a Dynamic Process}

The system of the European Community and the European Union (EU) - as they are called since the treaty of Maastricht (signed in 1992 and entered into force on 1 November 1993) has never been stable in the medium term. In five decades, the number of countries involved has increased from 6 to 25 while the scope of common actions has been very much developed and diversified. The basic elements of the institutional setting however had been settled since the beginning, i.e. since the establishment of the European Coal and Steel Community (ECSC) by the Treaty of Paris which came into force in 1952. There have been only a small number of adjustments since then: the increase of budgetary autonomy of the Communities in the early nineteen seventies, the progressive institutionalisation of the meetings of Heads of State and Government - known as European Council ${ }^{6}$ since the single European Act of 1986 - the direct election of the European Parliament since 1979 and the creation of a Committee of the Regions in 1992; the new European Constitution of October 2004 includes a number of further important changes. In this sense the European experience demonstrates how flexible regional integration can be, and how flexibility is a condition of success, if - and only if - a number of basic features have been designed in order to cope with this flexibility.

\subsection{Growing membership and scope, from the ECSC of Six in 1951 to the EU of the} Twenty Five in 2004

The main feature of the evolution of the ECSC/EEC/EC/EU system is that it has been constantly growing in membership and scope. It is true that membership remained stable from 1951 to 1972 . These were the founding years during which the Communities went through the whole of the transition period that had been foreseen for the establishment of the customs union and common market.

\footnotetext{
${ }^{6}$ The similarity of names often create confusions in the minds of none experts, between the 'European Council' (meeting of the Heads of State or of Government of the 25 EU member States), the 'Council' (official Council of the European Union - often called Council of Ministers) which is one of the four major institutions of the EU, composed of ministers of the member states representing their national government, and the Council of Europe, a continent wide organization of 46 member states comparable to the Organisation of American States.
} 
This stability however was never considered as a pre-condition nor planned. Stability resulted first from the hesitations of Great Britain who did not want to join the France, Germany Italy and the three Benelux countries $^{7}$ who established the ECSC and EEC. The British government did not want to join the experiment of European integration before some results had been achieved, preferring to set up a free trade area with other Western European countries, the EFTA (European Free Trade Area). The success of the European Communities and European Union gradually attracted almost all EFTA members, to start with the United Kingdom $^{8}$. Once it became clear that the Common market was really being established, the British government applied for membership, but the United Kingdom was kept out of the European Communities due to the opposition of France to British participation from 1962 to 1969.

This was due mainly to the positions the French President, General De Gaulle, who twice opposed his veto to continuation of negotiations that had just been started in 1962 and again when they tried to resume them in 1967. First he feared that British participation might endanger the French leadership in the process of integration. Second, he also considered that the United Kingdom's ties with the United States of America as well as its economic links with the rest of the Commonwealth, and the traditional British policy of openness to world trade, would water down the project of continuing economic and political integration into a mere free trade zone that would tend to include the entire Commonwealth and maybe the USA. A third reason for opposing Britain's entry into the Common Market was probably that De Gaulle feared that the English language would become the main communicating language in the European Communities' institutions. It is only after his resignation in 1969 that his successor Georges Pompidou accepted resuming negotiations. This led to the enlargement of the Communities to Denmark, Ireland and the United Kingdom on 1 January 1973 after three and a half years of intense diplomatic and technical negotiations between the six original Community member states and four new applicants (including Norway which eventually decided not to join the Community after a negative referendum in 1972).

\footnotetext{
${ }^{7}$ Belgium, the Netherlands and Luxembourg had formed a customs union and a common market in 1948. From 1815 to 1832 the three countries had been part on single state - the Kingdom of the Netherlands, until the Belgians won independence with the help of England and France; Luxembourg became fully independent from the Netherlands in 1865, when the personal union between the King of the Netherlands and the Grand-Duke of Luxembourg ceased.
} 
The French President De Gaulle's opposition to Great Britain was expressed in policy terms by the idea that European integration had to be deepened before the Communities could be enlarged. This is a view that keeps being repeated over time since four decades, but since the early seventies - i.e. since the end of the transition phase of 12 years which had been foreseen for setting up the common market which was at the heart of the EEC - both deepening and enlargement have been pursued successfully together. According to circumstances it might seem that the priority was at certain times put upon deepening or on enlargement.

\subsubsection{Deepening integration}

As soon as the ECSC had been established in 1952 by the six founding member states, their governments - especially those of France and Italy - took new initiatives in the direction of deepening integration. Some of them were unsuccessful : the project of a European Defence Community as well as that of a political Union which were launched in 1952 were stopped after two years by lack of consent on the objectives between the six governments and especially due to the divisions amongst the French political parties and inside some of them. But as a matter of fact most of the other projects went off the ground and became successful.

In 1956-58, the Treaties of Rome were negotiated and signed. They would establish a customs union and a common market - in the framework of the EEC - and an embryo of a common energy policy - in the framework of EURATOM ${ }^{9}$.

In 1965-70, efforts concentrated first on finalising the Common market, through the setting up of the customs union (which was achieved on $1^{\text {st }}$ July 1968, 18 months ahead of schedule, notwithstanding the political crisis of the May 1968 student movements which resulted in some economic difficulties in France and Italy), and through implementing the common agricultural

\footnotetext{
${ }^{8}$ EFTA still exists but its membership only includes Norway (4,5 million inhabitants), Switzerland (7,4 million), Iceland (288 000) and Liechtenstein (40 000 inhabitants) for statistics of the EU member states see table 2.

${ }^{9}$ This project of a common energy policy was the result of the Suez crisis in the autumn of 1956, where European countries suddenly realized how dependent they were of oil stemming from the Middle-East, a resource that had been largely controlled by Great-Britain and France until then. Political changes in the Middle-East and the end of the British and French mandates over some Arab countries had totally changed the scene. However, the initial project never reached the importance it seemed to have in the design. EURATOM exists and functions as an organization which has a number of functions in the organization of the market of nuclear energy and research for civil purposes as well as in the field of security of nuclear installations, but energy policies, especially in the nuclear sector, have very largely remained in the field of national policy-making.
} 
policy. Second, the Communities' institutional setting was further developed through the merger of the executives of the ECSC, the EEC and EURATOM in one Commission and one Council of Ministers, notwithstanding a deep crisis between the French government and the five others on the future functioning of the Commission during the second semester of 1965.

From 1970 to 1975 while negotiations for the first enlargement of the Communities to new member states were concluded, projects for a monetary union were explored - but remained unsuccessful at that time, due to the unilateral decision of the United States to put an end to the Bretton-Woods system of changes - and new common policies were launched in the fields of environment and regional development ${ }^{10}$. Institutional deepening was also further developed by budgetary reforms and the decision to have the European Parliament directly elected, instead of being composed of representatives of national Parliaments.

In 1985-86 (while the negotiations for the third enlargement were finishing) efforts concentrated on the institutional changes needed in order to achieve the internal market by 1993. The Single European Act which was signed in 1986 therefore set up the procedural tools in order to suppress remaining technical and administrative impediments to the free circulation of goods, services, labour and capital.

In 1990-1991, while the territory and population of the European Communities increased substantially due to the reunification of Germany ${ }^{11}$, new efforts concentrated on the establishment of a monetary union and the further development of the political dimension by creating an embryonic European citizenship and institutionalising cooperation in the fields of foreign affairs, security, police and justice, which resulted in the Treaty of Maastricht.

Further deepening was undertaken in 1996-97 with the preparation and signature of the Treaty of Amsterdam, through extending the scope of Community action especially in the

\footnotetext{
${ }^{10}$ Regional policy is since then an internal European Community policy aiming at correcting economic and social imbalances between member states and inside member states. The term region in this context refers to regions inside each member state.

${ }^{11}$ After the collapse of the East-German regime and the fall of the Berlin wall on 3 October 1969, economic reunification of Western and Eastern Germany was achieved by the agreement on monetary union which entered into force on 1 June 1991, and political reunification with the agreement on the integration of Five EasternGerman Länder into the Federal Republic of Germany, which entered into force on 3 October 1991. This was considered as a purely internal German matter by the EEC institutions and the governments of the member states.
} 
fields of police and justice, while implementing the monetary Union which formally started on 1 January 1999 and acquired visibility with the replacement of national currencies by the Euro in eleven out of fifteen member states on 1 January 2002.

Further deepening was again undertaken in two fields. In the field of citizenship a Charter of Fundamental Rights of the European Union was adopted in December 2000, and the signature of the Treaty of Nice one month later allowed for new Community actions. This treaty also reformed the judicial institutions of the EC/EU in order to allow them to cope with the growth of activity due to both deepening and enlargement. Some institutional engineering had also been done (on the mechanisms of majority voting) in order to try and cope with the new enlargements which had taken place in 1995 and even more those which were to come with at least thirteen ongoing applications of countries who wanted to become members of the EU.

As soon as the content of the Treaty of Nice had been approved by the European Council in December 2000, new initiatives were undertaken which led to the adoption of a Treaty establishing a Constitution for Europe in October 2004, while the incremental development of common policies in the fields of foreign and security policies as well as cooperation in the fields of police and justice were continuing.

\subsubsection{Enlarging the European Communities and Union}

Enlargement was central in a number of periods which, to a certain extent, overlapped with periods of deepening.

1969-1972 was devoted mainly to negotiations with Denmark, Ireland, Norway and the United Kingdom. While the people of Norway rejected by way of referendum their government's proposal to join the Communities, the three other countries joined on 1 January 1973. This changed considerably the nature of membership for two reasons: the regional economic imbalance in the Community increased due to the fact that Ireland and the most Northern part of the United Kingdom had a quite lower level of GDP per capita than the rest of the Community, whereas previously only Southern Italy and Corsica (an island which is part of France) showed a serious imbalance with the other regions. More importantly, Great Britain 


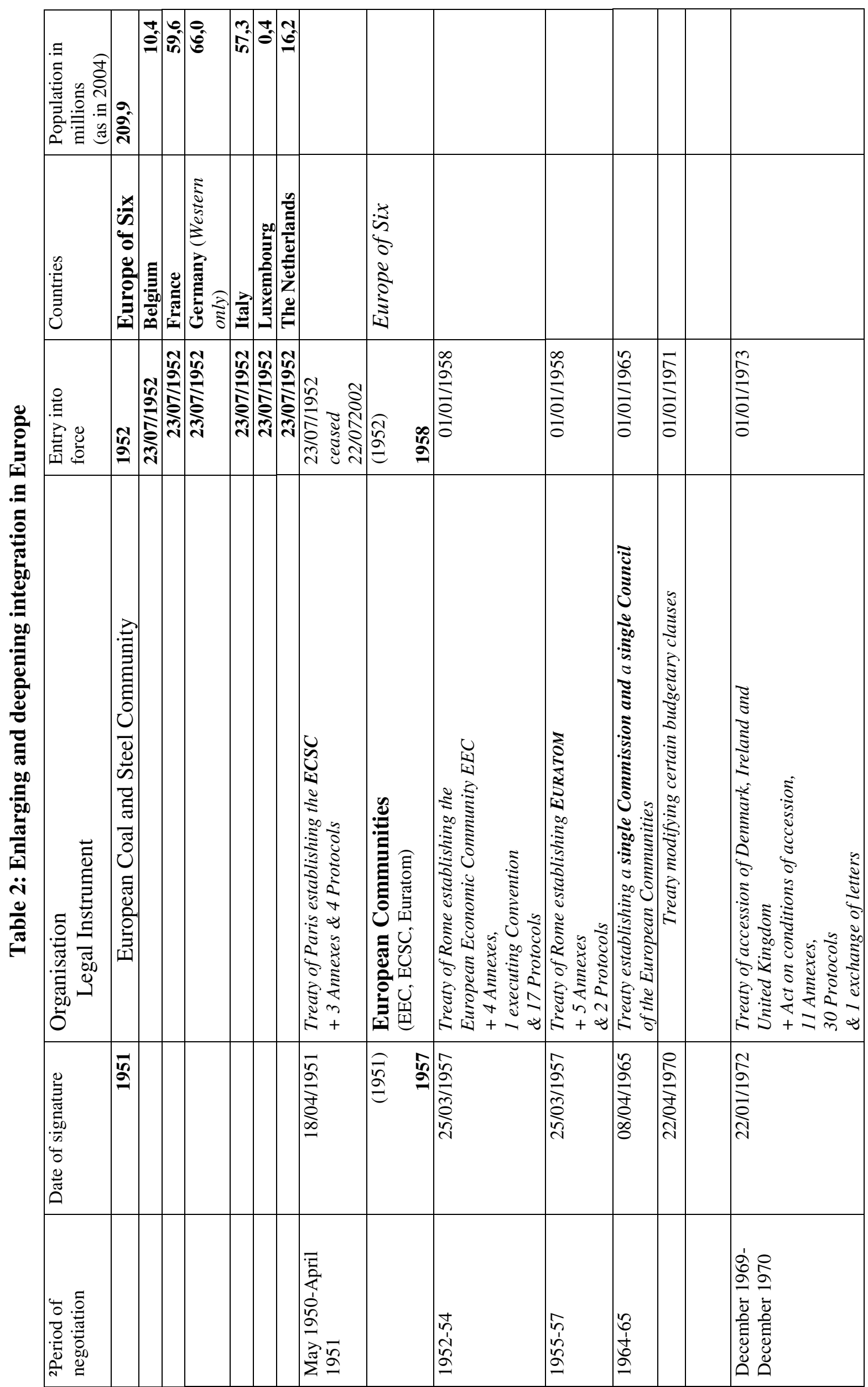




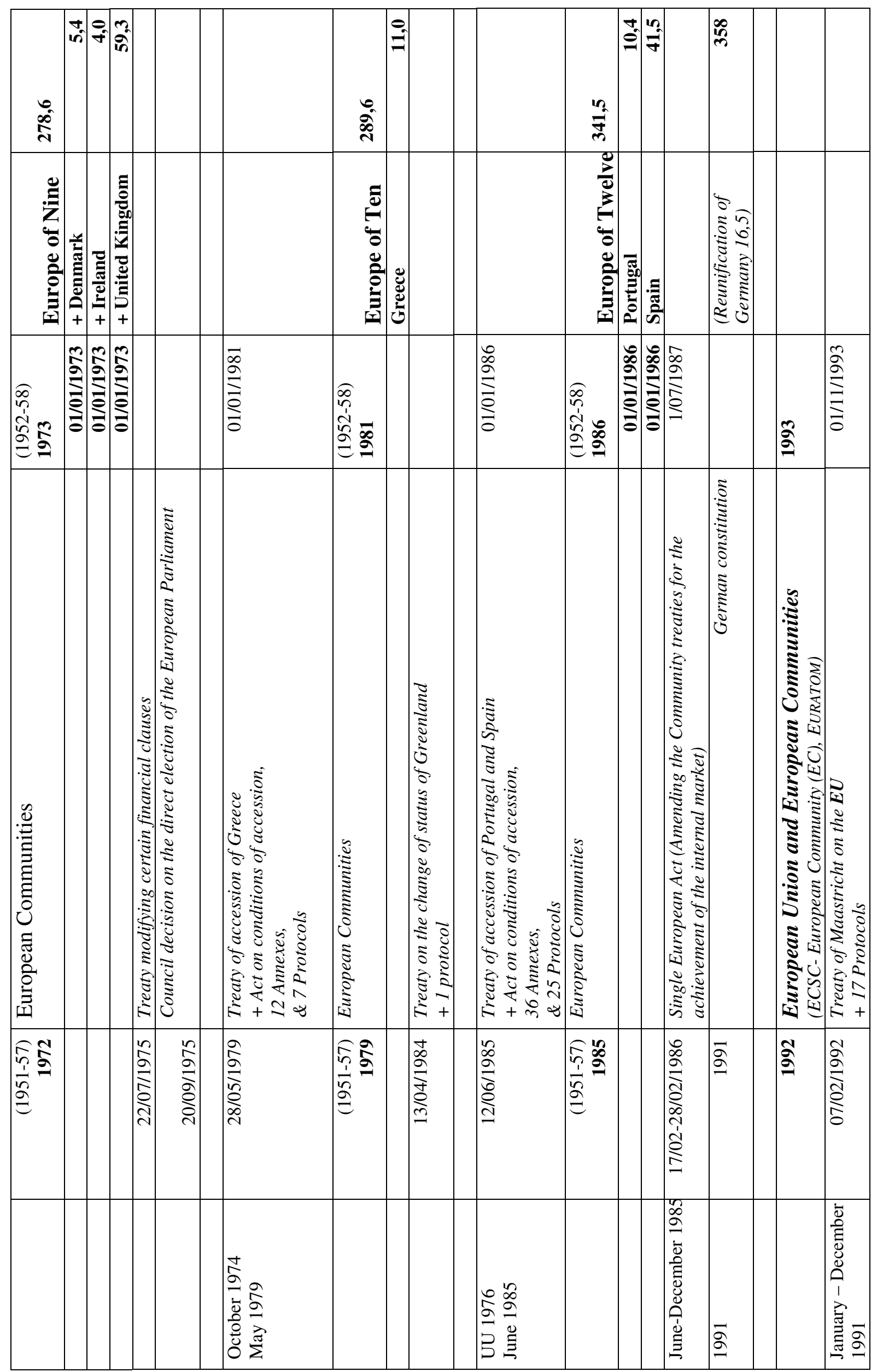




\begin{tabular}{|c|c|c|c|c|c|c|c|c|c|c|c|c|c|c|c|c|}
\hline & $\overrightarrow{8}$ & $\infty 0^{\circ}$ : & तु & & & 年 & & & $\vec{\theta}=$ & $=$ & $\stackrel{\overbrace{}}{\sim}$ & & 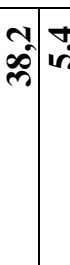 & 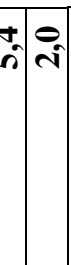 & & \\
\hline & 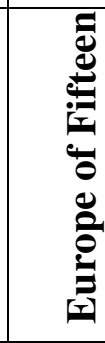 & 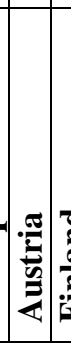 & 总 & & & 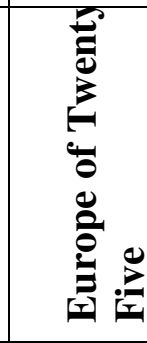 & & 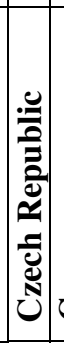 & 势 & . & 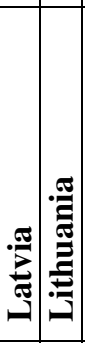 & & 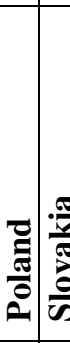 & 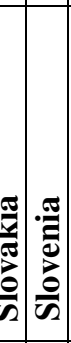 & & \\
\hline 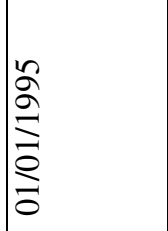 & 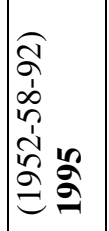 & & & $\begin{array}{l}\stackrel{2}{2} \\
\frac{\sqrt{2}}{2} \\
ٍ\end{array}$ & & 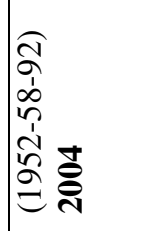 & 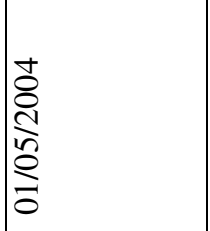 & & & & & & & & : & 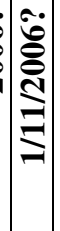 \\
\hline 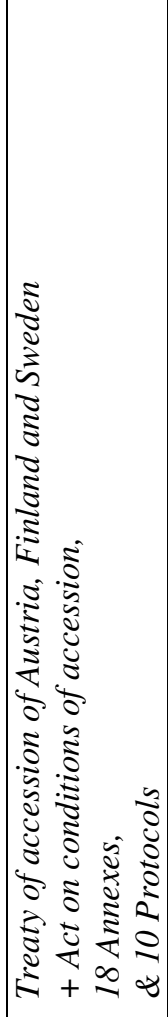 & 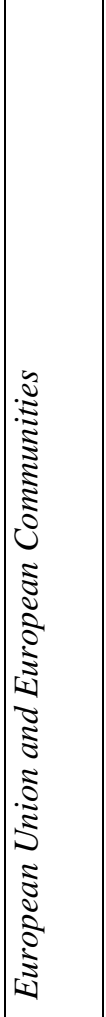 & & & 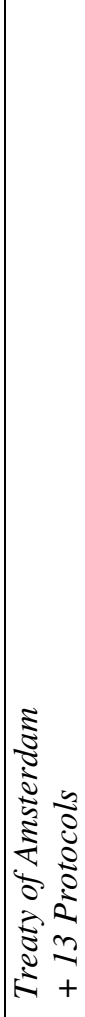 & 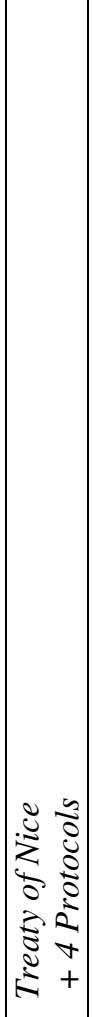 & 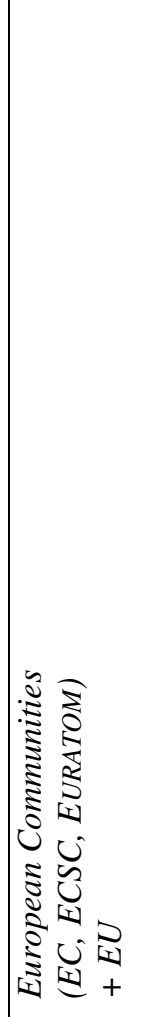 & 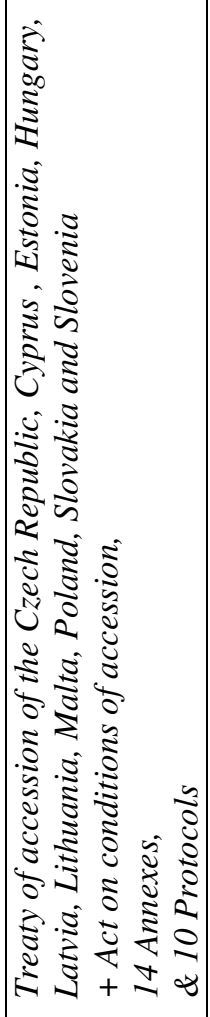 & & & & & & & & 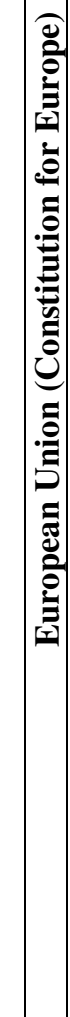 & 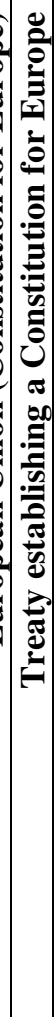 \\
\hline 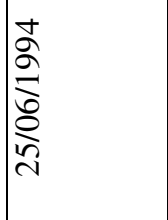 & 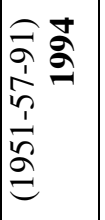 & & & 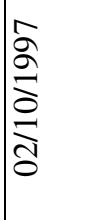 & 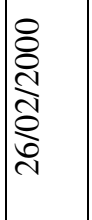 & 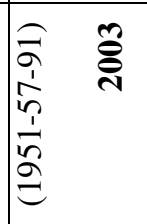 & 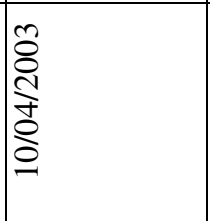 & & & & & & & & ఫ্ণ & 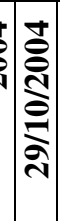 \\
\hline 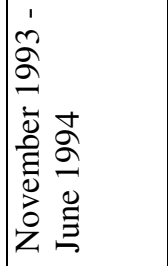 & & & & & & & 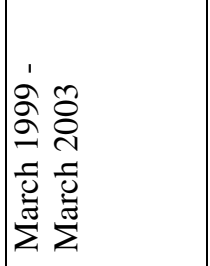 & & & & & & & & 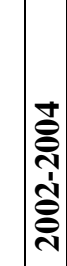 & \\
\hline
\end{tabular}




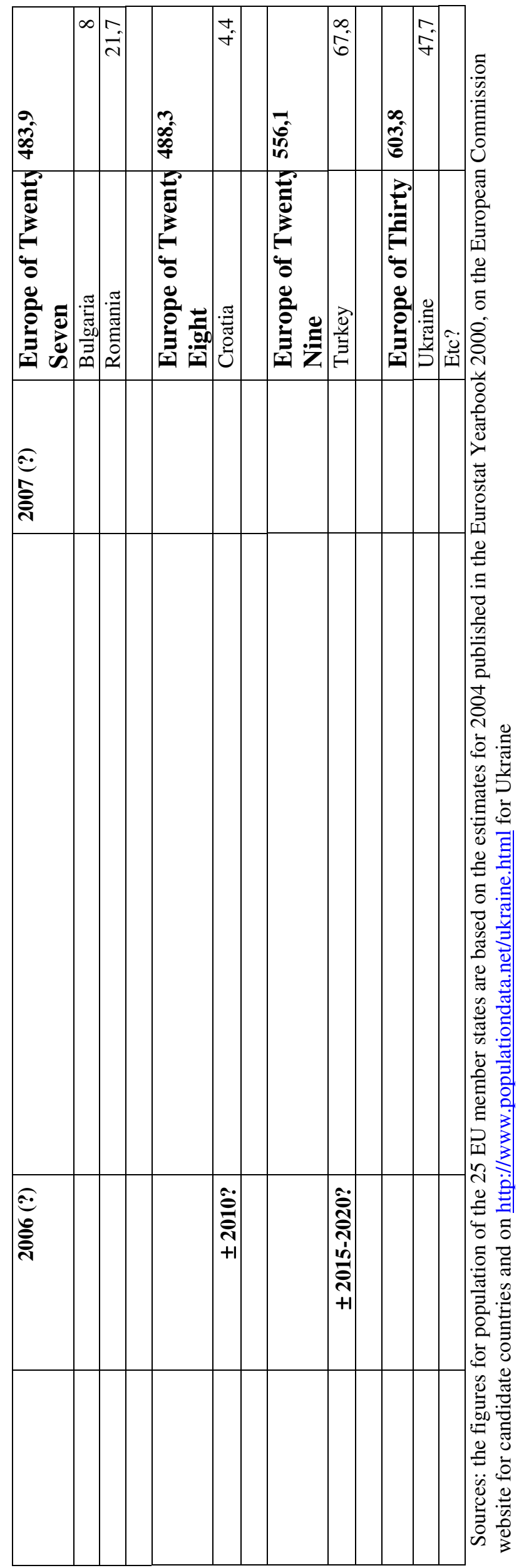

EUI WP LAW 2005/11 
had strong ties with the remainders of its colonial Empire, specific bonds with the United States of America, and a vision of European integration that did not fully overlap with that of the founding countries. Denmark shared the UK's positions in this respect.

The fall of authoritarian regimes and military dictatorships in three southern European countries in 1974-1976 opened the way for new negotiations for enlargement. Greece became a member on 1 January 1981, Portugal and Spain became members on 1 January 1986. Here again these enlargements resulted in widening the gap between rich and poor regions in the Community and increasing the number of the latter. Furthermore, democratic tradition was very recent in the three new member states, which saw their participation in the European Communities as a way to stabilise their political life through economic development and embedding them in an environment of longstanding traditions of democratic pluralism.

The end of the nineteen eighties saw a number of new applications for membership which resulted in Austria, Finland and Sweden - who were still members of EFTA - joining the EC/EU on 1 January 1995, while in Norway a second referendum on accession resulted again in a negative vote.

The collapsing of communist regimes in Central and Eastern Europe led to a new wave of applications which necessitated important efforts from 1990 onwards. Association agreements were first adopted in the framework of a strategy for future accession and then, from March 1999 onwards formal negotiations for accession started. These resulted in ten new countries becoming EC/EU member states on 1 may 2004. Further enlargements are foreseen for 2007 (Bulgaria and Romania). Two of the ten new members of 2004 were not former communist countries, but very small island-states (Malta and Cyprus) for which the advantages of full participation were not necessarily bigger than their mere association with the EC, which was already effective since a number of years ${ }^{12}$. Even more than for previous enlargements this has increased the economic and social imbalances between member states, resulting in the fact that a number of regions of previous member states which were considered as relatively poor went over the threshold of medium GDP per capita. The difference of views about scope and Croatia

\footnotetext{
${ }^{12}$ Turkey is also in a customs union with the EC since 1996 without being a member of the EC. Iceland, Liechtenstein and Norway form with the EC member states the so-called European Economic Area, which started in 1994, which is a free trade area without a customs union, and which shares common policies with the EC.
} 
and with Turkey, while in January 2005 the newly elected President of Ukraine has also announced his intention to present an application to join the EU. The differences in terms of political culture, economic and social organisation of those two big countries indicate that negotiations will be far longer than they have been for recent enlargements and that their outcome is still not obvious.

As a matter of fact the two processes - enlargement and deepening - have really been going hand in hand, to the extent that 1986 was both the year of enlargement to Portugal and Spain, and of the adoption of the Single European Act, which paved the way for the completion of the internal market on 1 January 1993. In the same way, 2003-2004 have been the years of enlargement to ten new member states and of the preparation of the Constitution for Europe. For the sake of clarity, it is worthwhile to examine separately the progressive enlargement of the EC/EU and the deepening of integration, but without ever forgetting the fact that there was no contradiction between these two processes.

\subsection{Why enlargement did not lead to a reduction of the scope of integration}

Contrary to what has been feared from time to time, enlargement has never led to a reduction of the scope of common actions. Two techniques have helped in this: the careful use of transition periods and the concept of acquis communautaire. These are the main tools that helped to cope with the need for differentiation resulting of growing asymmetries between member states due to enlargements.

\subsubsection{Transition periods}

Each of the successive enlargements of the EC/EU has been accomplished with transition periods. Participation of the new countries in the EC/EU institutional setting is always complete from the day of accession of a new member state - i.e. the day of entry into force of the relevant accession treaties, which means that they may fully participate in all decisions relating to the development of policies and legislation. However, a big number of constraints and advantages which result of being part of the internal market and of being subject to common policies do not have consequences overnight. They are being implemented 
progressively, following deadlines and steps which are foreseen in detail in the Act on the conditions of accession, its Annexes and Protocols. These documents usually contain the list of all existing legislation and policies and go in details about the conditions and schedules of their application.

The technique of transition periods had been used with success by the founding member states, who had foreseen a transition period of 12 years between the entry into force of the Treaty of Rome on 1 January 1958, and the full opening of borders for the free movement of goods, persons, services and capital on 1 January 1970. The EEC Treaty, its annexes and protocols had organised three different periods for the progressive reduction and elimination of barriers to the free movement of goods, services and persons ${ }^{13}$, as well as for some of the accompanying policies. In some cases, the treaty did not foresee binding deadlines for the full development and implementation of a common policy. In the case of the common agricultural policy, a fierce debate between member states occurred before an agreement could be made in 1962 - to some extent more difficult than the negotiation of the Treaty of Rome. In the case of transport policy, the treaty was only somewhat detailed in matters of ground transportation (rail and road) but needed further detailed norms in order to be applicable to air transport. As nothing of the like had been achieved almost thirty years after, the European Court of Justice (ECJ) decided to open up air transport to competition rules in 1986 (Case Nouvelles frontières of 30 April 1986), a ruling which radically changed the conditions of air transport in Europe and pushed the member states to finally agree upon a common policy. As opposed to these problematic cases, the customs union had been achieved on 1 July 1968, i.e. one and a half year ahead of the deadline that had been put in the treaty. This may most probably be explained by the care that had been given by the negotiators of the Treaty of Rome in scheduling in detail the full dismantling of tariffs inside the Common Market. Jacques Delors, who was President of the European Commission from 1985 to 1995, draw the lessons from these precedents when he suggested to put a firm deadline for the completion of the internal market - 1 January 1993 -, and when he launched a campaign of public declarations in 1987 in order to first raise consciousness and then get support on the side of the economic and socials actors within member states.

\footnotetext{
${ }^{13}$ Free movement of capital only became effective with a council directive which was adopted in 1988 .
} 
When the treaty of accession of Greece was negotiated in the late seventies, insufficient attention was given to the foreseeable difficulties of adaptation for a country which was far less developed than the other nine member states. The consequence was that Greece could not meet the deadline, and asked for an extension, which delayed its full integration into the common market for about five further years. This explains why the negotiation with for the following enlargement (Spain and Portugal) took far more time. In the case of the 1995 enlargement to Austria, Finland and Sweden, the negotiations were much shorter, and so were the few deadlines for delayed application of some policies and legislation. This could be achieved because those countries were already fully part of a free trade agreement with the EEC since ten years, which covered an important part of the fields of the internal market, and were also parties to the EEA which had entered into force in 1994 and integrated them into some of the common policies of the EC. In a somewhat similar matter, the formal negotiations with the ten countries which joined the EC/EU in 2004 may seem rather short (four years), but those countries had already concluded association agreements with the EC more than ten years earlier, with the aim of preparing accession.

\subsubsection{The acquis communautaire}

When the negotiations with the United Kingdom were opened in December 1969 the six founding member states agreed upon the principle that a new member state should not be allowed to select amongst different parts of the existing treaties, policies and legislation, and had to accede to the entire acquis - i.e. all the treaty clauses, the policies that have been established and the legislation that has been adopted before its accession. They also agreed upon the principle that existing policies should not be revised in the framework of negotiations for enlargement: if the member states or future member states deemed it necessary to undertake such reforms, they should be started only once the accession treaty was in force. This avoided mixing up too many issues and always fostered maximum solidarity between existing member states.

The rigidity of the principle that candidates had to accept the entire acquis communautaire has however always been accompanied by flexibility in order to accommodate specific concerns. Transition periods have been different from one member state to another, from one policy field to another. For instance, the transition for the application of full freedom of 
circulation of labourers to Portugal was not the same as for Spain, whereas they both became members of the European Communities on the same day. This has to be understood in the light of both the presence of about a million of Portuguese in France even before Portugal joined the EC, and of the fact that Portuguese decolonisation in Africa would probably bring an important number of immigrants to the European part of Portugal. Further flexibility has been provided by agreements in the framework of treaty reform for the deepening of integration: in some cases, exemptions have also been foreseen, as in the case of the 'social protocol' adopted together with the Treaty of Maastricht in 1992, in which the United Kingdom did not want to participate. In the same way, when the principles of the economic and monetary union (EMU the future Eurozone) were established in the framework of the Treaty of Maastricht, Denmark and the UK were allowed not to participate. Neither Ireland nor the UK participates in the 'Schengen ${ }^{14}$, system, which allows for the suppression of border controls on persons travelling within the EU.

I has to be stressed once again that transition periods and exemptions normally only apply to policies and rules of economic and social integration, not to the institutional setting. The only important exception to this principle is the EMU: only member states who participate in the EMU (which is embedded in the European Community) are participating in the accompanying institutional setting: the European Central Bank (ECB) and the System of European Central Banks (SECB). However it should be noted that all EU member states (not only those of the Eurozone) participate in meetings of the Council of ministers that examine the performance of the members of the EMU, who are bound by very strict rules applying to their economic and budgetary policies.

\subsubsection{Differentiation and asymmetries between EC/EU member states}

The characteristics of the countries which were involved in the successive rounds of enlargement are very different in terms of size (both population and territory, see tables 1 and 2) and wealth (see table 3), but also in terms of language and culture.

\footnotetext{
${ }^{14}$ Schengen is a small city in Luxembourg, where the relevant agreement between a limited number of EC member states was first signed in 1985. The content of this agreement and the subsequent convention for its implementation, as well as the decisions, rules and policies agreed upon in this framework (the so-called Schengen acquis), were integrated into the EC/EU treaties by the treaty of Amsterdam in 1997, but the UK and Ireland were still exempted from participation.
} 
Table 3: comparative economic development of EC/EU member states

\begin{tabular}{|c|c|c|c|}
\hline Country & 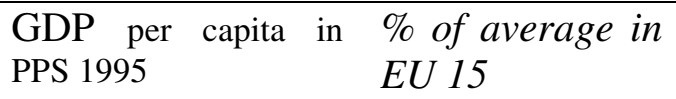 & $\begin{array}{l}\text { GDP per capita in } \\
\text { PPS } 2004 \text { (forecasts) }\end{array}$ & $\begin{array}{l}\text { \% of average } \\
\text { in EU } 25\end{array}$ \\
\hline Austria & $20240 \quad 115$ & 27910 & 120 \\
\hline Belgium & 19190 & 26830 & 116 \\
\hline Czech Republic & & 16230 & 70 \\
\hline Cyprus & & 19550 & 84 \\
\hline Denmark & 19940 & 28400 & 122 \\
\hline Estonia & & 11480 & 49 \\
\hline Finland & 16890 & 25500 & 110 \\
\hline Germany & 19060 & 24900 & 107 \\
\hline Greece & 11520 & 18880 & 81 \\
\hline France & 18400 & 26150 & 113 \\
\hline Hungary & & 14130 & 61 \\
\hline Ireland & 15870 & 30370 & 131 \\
\hline Italy & 18420 & 24600 & 106 \\
\hline Latvia & & 9680 & 41 \\
\hline Lithuania & & 11610 & 50 \\
\hline Luxembourg* & 28540 & 47920 & 206 \\
\hline Malta & & 17170 & 74 \\
\hline Netherlands & 19200 & 27270 & 117 \\
\hline Poland & & 10940 & 47 \\
\hline Portugal & 11670 & 17110 & 74 \\
\hline Slovenia & & 18070 & 78 \\
\hline Slovakia & & 12240 & 53 \\
\hline Spain & 13420 & 22190 & 96 \\
\hline Sweden & 18890 & 26260 & 113 \\
\hline United Kingdom & 17660 & 27820 & 120 \\
\hline
\end{tabular}

Source: Eurostat Yearbook 2004. GDP = Gross Domestic Product; PPS = purchasing power standards

* The very high GDP per capita of Luxembourg has to be related to the very important number of financial institutions in this microstate of less than half a million inhabitants.

As far as languages are concerned, suffice it to remind the reader that from 1951 to 1972 there were only four official languages (for six member states) Dutch, French, German and Italian, from 1973 to 1980 six languages for nine member states (with the addition of Danish and English), and that each of the subsequent enlargement brought almost as many new 
languages as new member states ${ }^{15}$ : in 2004 there are twenty one official national languages in the whole of the EU member states, to which a number of official regional languages have to be added (like Basque, Catalan and Galician in the case of Spain). This cultural and above all linguistic differentiation makes for an obvious difference (at first sight) between Latin-America and Europe, especially as the difference between most European languages are far deeper than between Portuguese and Spanish.

However, there is no equivalent in Europe of the asymmetries which are to be found in terms of size of territory and population, as well as economic structure between Brazil on one side, and Spanish speaking countries on the other. Until now, and even though there have been important differences in the economic structures of European countries as far as the relative importance of agriculture, services and industry are concerned, there have always been both enough complementarities and common sector interests between the countries participating in European integration, in order to foster both economic exchanges and the development of common policies that were of interest to all member states. This is somehow confirmed by two of the countries have which have remained outside the EC/EU until know: Norway, which draws a very substantial resources from the presence of oil in its part of the North Sea Continental shelf - whereas the other European countries heavily rely on energy imports - , and Iceland, whose economy is dominated by fisheries.

The striking element in five decades of European integration is that each successive enlargement has increased the heterogeneity of EC/EU membership- with the sole exception of the accession of Austria, Finland and Sweden in 1995.

One central question in 2004 is whether the last enlargement to 10 new member states presents a genuinely new challenge or just a repetition of past experiences. There is a difference in terms of overall numbers of member states: an increase of 10 members at the same time, whereas previous enlargements never included more than three new countries which joined the old ones at the same time. Furthermore, eight out of ten new members, countries of Central and Eastern Europe, had been totally separated from the Western countries involved in European integration until fifteen years before accession. During forty years, from

${ }^{15}$ With the exception of Austria, whose language is German, and of Cyprus, whose language (in 2004) is Greek. 
the late nineteen forties to the early nineteen nineties, three of them had been part of the SovietUnion $^{16}$ and the other five ${ }^{17}$ had been totally embedded into the Soviet sphere of influence. Together with the Soviet Union had been members of the military alliance of the Warsaw Pact which was dissolved in $199 ?^{18}$, and they had only very recently joined the military alliance of the Northern Atlantic Treaty Organisation (NATO - including the USA and Canada, 12 Western European Countries and Turkey), which had been the main opponent of the Warsaw Pact. For forty years they had a centralised planned economy and they were embedded in an international system of economic specialisation which was largely decided by the Soviet government in the framework of the COMECON; a system of planed cooperation totally opposed to the EEC, which is based on freedom of circulation of goods, services, labour and capital without any central guidance. Finally their political and social systems had been dominated by the doctrine of Marxist-Leninist principles, totally opposed to those of pluralist democracy applied in Western Europe. However fifteen years have elapsed between the collapse of the Eastern European ensemble of communist regimes; during these fifteen years the countries concerned have made enormous efforts to transform into pluralist democracies and market economies. Only time will tell if the 2004 enlargement creates genuinely novel problems for the integration of the new members, or if there are similarities with the precedents of the integration of Greece, Portugal and Spain, three countries who had only recently recovered their internal freedoms when they entered the European Communities, after decades authoritarian leadership $^{19}$, and whose economic development was far below the average of the EEC countries.

The issue of a possible accession of Turkey in the next ten to fifteen years is also raising a number of questions, especially as far as cultural heterogeneity is concerned: historically the societies of the present EU member states were strongly influenced by the fact that most of their population had been of Christian religion, whereas the major part of Turkish population is of Muslim belief, even though the separation between political institution and religion is total

\footnotetext{
${ }^{16}$ The Baltic states of Estonia, Latvia and Lithuania.

${ }^{17}$ Eastern Germany had joined the EEC in 1991 through its voluntary incorporation into the Federal Republic of Germany.

${ }^{18}$ Western members of the EU had been either members of NATO or neutral countries (Austria, Finland, Ireland and Sweden).

${ }^{19}$ More then four decades for Portugal, four decades for Spain, seven years of military dictatorship for Greece, which had followed about six decades of great political instability, where periods of democracy and dictatorship had alternated.
} 
since the "revolution" of Kemal Atatürk in the early nineteen twenties. For the first time in European integration, public opinion in the member states is quite divided over the mere possibility of opening negotiations for a possible accession of a candidate country. The decision to open these negotiations as of October 2005 could only be taken by the European Council in December 2004 together with a number of statements pointing to the fact that negotiations did not mean that Turkey would certainly accede to the EU, and that anyway negotiations would need very a long period (ten to fifteen years) to be completed.

\subsubsection{Differentiation in the scope of integration}

The fields covered by European integration have also been increasingly differentiated and varied. The scope of integration was limited to one specific market - coal and steel - during the first years of the experience (1952-58). It only included six countries which shared common economic features. As a consequence the organisation of the coal and steel market had the same strategic importance for their industries. The biggest parts of the concerned resources were located in a geographic region common to five of the six countries (France, Germany and the three Benelux countries). The choice of this field for the first steps in European integration was not only due to the economic prominence of the coal and steel market, but also to the fact that the armament industry was part of that market: this choice was also the consequence of the fear of a unilateral rearmament of Germany, in a situation - the Korea which opposed the USA and their allies to the Soviet Union and China - which made it clear that Germany could not remain a totally demilitarised country, too weak to resist a possible attack by the Soviet Union. If the scope of integration was at first limited to the coal and steel market, the project was however from the beginning part of a broader strategy to develop economic and political integration in a far more comprehensive way: the goal was to overcome the political opposition crystallising around two enemy countries - France and Germany - which had led to three wars in Western Europe within a period of seventy years ${ }^{20}$, including two World Wars, with several millions of death.

From 1958 onwards, integration extended to all aspects of market economy. It included negative integration - establishing a free trade area, a customs union and a common market based on the free movement not only of outputs (goods and services) but also of inputs 
(economic factors, i.e. labour and capital). It also included positive integration, i.e. common policies aimed at correcting market failures or at protecting specific economic fields common to the different countries. At the beginning these were the fields of transport and agriculture, both sectors considered as vital for the populations of the countries involved: when the negotiations for the EEC started, only ten years had elapsed since the end of World War II, a period where ground communications had been destroyed in large parts of the relevant countries, and where food supplies were rationed. Decolonisation in the late fifties and early sixties later led to the establishment of a specific policy of development aid - through the instruments of the Conventions that were signed in Yaoundé, later in Lomé and later in Cotonou between the EEC and newly independent countries of Africa, the Caribbean and the Pacific Ocean (ACP countries). The scope of integration was further extended during the seventies to environmental policy and regional development, a policy aimed at correcting imbalances between the different regions and countries of the EEC, renamed 'economic and social cohesion' after the Treaty of Maastricht in 1992. In the early eighties, it was further extended to research and innovation, sectors that were still considered as complements and corrections to the ongoing integration of markets.

Parallel to the development of the scope of integration in the European Communities, the governments of Western European countries steadily continued the development of intergovernmental cooperation an a vast number of fields - in the framework of the Council of Europe, which always include all EC/EU member states, but also always was composed of a far bigger number of members ${ }^{21}$. Intergovernmental cooperation was growing much faster between the countries that were member of the EC/EU than with others, and this lead to a progressive integration of new policies, in the framework of the EC/EU treaties. These new policies had a different scope, very little or not at all linked to market integration, including cooperation in matters of immigration, police and justice, as well as foreign affairs and security/defence.

\footnotetext{
${ }^{20}$ 1870-71 between Germany and France, 1914-1918 and 1939-1945 between these two countries again and their allies.

${ }^{21}$ In early 2005 the Council of Europe has 46 member states, including the $25 \mathrm{EU}$ members and countries as different than Russia - with an enormous territory that spans over Europe and Asia or Andorra - a micro state of a few thousands of inhabitants at the boarder of France and Spain in the Pyrenean mountains. Until the fall of the Berlin wall in 1989, the Council of Europe only included Western European countries (including Turkey).
} 
With the Single European Act of 1986, a progressive integration of all the new policies within the existing institutional framework and procedures started. It increased with the Treaty of Maastricht of 1992, with a clear differentiation of procedures between the fields of integration (mainly economic and social) in the European Community framework, and cooperation (in fields deemed as having a bigger political impact) in the European Union framework. Both the EC and the EU share the same institutions, but use quite different decision making procedures, with strong differences in the respective roles of the common institutions and the national governments. There is however a clear trend which leads to gradually 'communitarising' 22 fields of intergovernmental cooperation. This is especially clear since 1997: the treaty of Amsterdam provided for the transfer of the coordination of immigration policies from EU cooperation (so-called 'third pillar' of the Union) to EC integration (so-called first pillar). This trend form EU cooperation towards Community integration has been confirmed by the Treaties of Nice of 2001 and the Treaty establishing a Constitution for Europe of 2004.

Social policy has always been a very specific field in European integration. Both the treaties of Paris of 1951 and of Rome of 1957 had already a social dimension, based on two considerations. First, as the Common market was not limited to the free circulation of goods and services, but gave a prominent role to the free circulation of labourers, a number of elements of the labour law and social policies of the different member states had to be coordinated in order to allow for this free movement of labourers. Second, the idea was strongly embedded in the strategy leading to the establishment of a Common market that too big differences in social conditions could lead to unfair competition between industries, due to their geographical location in one or the other member state. This was considered as especially important in some fields of - especially in the field of labour law and labour conditions, like for instance equal salaries between men and women. On the other side, each of the member states had developed its own approach, institutions and procedures for the consolidation of the welfare state, and they have always considered that this would be endangered if too much power was transferred to the Communities in the social field. This is most clearly demonstrated by the fact that only eleven of the twelve member states agreed on the extension of integration procedures to a number of new fields of social policy and labour law in 1991-1992, when the

${ }^{22}$ In EC/EU jargon, "communitarising" means to apply the Community method (see section 2) to a specific field 
Treaty of Maastricht was being drafted. As these eleven countries wanted to go along notwithstanding the resistance of the British government, the twelve agreed upon the idea that such an extension of social policy competences would happen in the framework of a separate protocol, which was signed and ratified by only eleven member states. This was probably facilitated by the fact that many governments thought that the British Conservative government would be defeated in the next general elections, and that a new Labour government would happily subscribe to the content of this separate protocol on social policy. However the government led by John Major unexpectedly won the 1992 general elections; it was only after the 1997 general elections, won by the Labour Party led by Tony Blair, that the UK indeed .agreed to this protocol, the content of which was integrated into the EC treaty in 1997.

It is often said that integration started with areas that were not sensitive to claims on sovereignty (economic) and only recently extended to the core functions of sovereign states (money, police, foreign affairs, defence). This view may easily be contended: a customs union touches also upon one of the hard core sovereignty issues, and it had been foreseen in the Treaty of Rome, which entered into force on 1 January 1958. Quite remarkably, the transition period eventually was shorter by 18 months to the period which had been initially foreseen. The EC/EU experience shows that agreement on integration has been easier - from 1958 onwards - in those fields where there were either no significant oppositions of economic and social interests between member states, or when it was sufficiently clear that integration would result in a positive sum game, i.e. that all countries would benefit from it, whatever their differences in size, economic structures and social organisation. This is far more important than a somewhat fuzzy distinction between 'sovereignty v. low politics', clearly the asymmetries between EC/EU member states have not been until now of a nature that would impede finding a common core of interests. On the contrary where economic interests (and sometimes political interests, like in external relations) differ, there are more often complementary than opposite. This match between the nature of interests at stake and the diversity of participating countries is quite remarkable on the whole in the European experience, and certainly much more relevant to other experiences of regional integration than the specific elements of European policies and governance. They need to be fully taken into account when examining the possible relevance

of action. 
of the EU/EC institutional and legal setting to other projects or regional cooperation or integration.

\subsubsection{Diversity and common goals}

Last but not least, the lack of agreement between countries involved in European integration upon the finalité of this integration has been and remains an almost constant feature. In the French language finalité of European integration is mainly understood as its 'purpose', whereas in the English language the expression points at the ultimate stage to be reached by European integration: a Federal state? A confederation? Or an international organisation? It also point at its ultimate boarders: should Turkey or even Russia be included? Etc. The issues of 'ultimate stage' and 'ultimate boarders' have never been answered, because since the mid fifties there have always been divergences between member states upon this answer.

The more pragmatic conception of finalité in the sense of 'purpose' has always predominated, because the approach of some countries to the ultimate issues has been changing overtime. France, Spain or even the UK are typical examples of countries which at times have been favouring quick and deep integration ${ }^{23}$, and at other times favouring the intergovernmental method and the protection of national interests ${ }^{24}$. This predominance of a pragmatic approach to the issue of the purpose of integration in a number of countries ${ }^{25}$ is due to the fact that public opinion and political elites are often quite divided upon these issues. This phenomenon is developing within a growing number of member states: Ireland had the reputation to be a country that was almost unanimously in favour of integration, until the first referendum on the ratification of the Treaty of Nice in June 2001 had a negative outcome, due to the lack of enthusiasm of the supporters of further integration, which accounted for a very low turnout, and due to the growth of anti-integration opinion.

\footnotetext{
${ }^{23}$ France from the early fifties to 1958 , and again, during the presidencies of Valéry Giscard d'Estaing and François Mitterrand (from 1974 to 1995), albeit with a mix of proposals for more integration and for small steps through further use of the intergovernmental method; Spain under the socialist governments of Felipe González (1986-1996) and José Luis Rodríguez Zapatero (since March 2004); the United Kingdom under the Conservative government of Edward Heath (from 1972 to 1974).

${ }^{24}$ France especially under the government and Presidency of Charles de Gaulle, from June 1958 to April 1969, Spain under the governments of José María Aznar, from 1996 to 2004, the UK especially under the governments of Margaret Thatcher and John Major, from 1979 to 1997.

${ }^{25}$ In some countries, especially Belgium, Germany and Italy, most political parties and a vast majority of the population have on the contrary always been in favour of deeper and quicker integration.
} 
This feature of European integration, the lack of agreement on the exact scope of common goals, is fundamental for its relevance to other experiences, far more than understanding the implications of say the neo-functionalist theory, which may have a good ex-post explicative value, but does not present ready made solutions for new experiences. However, the lack of agreement upon the finalité should not be exaggerated: once the United Kingdom decided to join the European Communities and to leave the EFTA that it had set up as an alternative to the EEC with a number of European countries not participating in the Communities, the core agreement which is common to all member states is that the EC/EU is more than a free trade agreement and customs union, and that it necessarily has some kind of political dimension.

\subsection{Conclusions to section 1}

European integration is a dynamic process, which has always been expanding until the present period. In terms of governance, the issue to be examined is whether and how the institutional and legal settings and their implementation have been adapted to this dynamism, to what extent they have been fostering dynamism or impeding it. There is no clear-cut answer to this question.

As far as legal instruments are concerned, the EC has benefited from being able to use specific normative instruments (directives, regulations, decisions etc.), which differ conceptually and technically from laws and regulations as they are usually known inside countries. This is especially true of the instrument of the directive, which has been designed, and to a great extent used to respond to this dynamism ${ }^{26}$. This goes together with an appropriately designed judicial system which has two major features: the possibility for the Commission to go to Court independently - i.e. without needing any approval of national governments at any stage, contrary to the usual system of international justice -, and the possibility for national courts to address questions for preliminary rulings to the European

\footnotetext{
${ }^{26}$ Two features of directives are specially relevant:

1. though being agreed in the framework of Common institutions and being fully binding to member states, they leave a more or less important margin for manoeuvre to member state's institutions in order to be translated in national law, and

2. Directives always set two deadlines: a date for their entry into force, and an ultimate deadline for their transposition into national law. Usually there is a time span of about two years between entry into force and the deadline for transposition.
} 
court, by which they participate in ensuring effective application of European law. This second feature is essential to the functioning of the network of European and national courts, and has been most effective due to the techniques used by the European Court of Justice, which draws upon a big number of different member states' experiences in judge made law.

For the institutional setting, the advantages of an independent Commission with a monopoly on formal policy initiative, as well as the flexibility of majority voting in the Council - when available - are also common knowledge. A far more intense discussion in view of the possibility to transpose this setting to other regional experiences is however still lacking to my view.

These two features have often been used after enlargement in order to give more time to some countries in order to transpose the directives, or to restrict the scope of these norms during a certain period. 


\section{The 'Community Method': the European Solution to Regional Integration}

In the framework of European integration, the expression 'Community method ${ }^{27}$, (méthode communautaire in French) is being used both by academics and practitioners when referring to the genuinely European solution to regional integration which has been developed since the early nineteen fifties. The institutions of the EC/EU are more than often presented as models for the institutional setting of a system of regional integration, and are usually quite well known by experts involved in developing such systems outside of Europe.

Suffice it to recall as a summary that the four ${ }^{28}$ major EC/EU institutions are:

i. an independent Commission; it is composed of personalities who are appointed for a fixed term (5 years), who are not supposed to represent the interests of their countries of origin, but to promote the common regional interest through collegial action and who are supported by permanent staff; it has three functions:

○ proposing all the decisions needed for the good functioning of the EC's internal market and for the development of common policies;

○ implementing those common policies which need centralised action - only a minor part of the whole of common policies, as in most cases the implementation of common policies is the task of member states institutions: governments, parliaments and public administration ;

- monitoring the good application of EC law by member states institutions, and taking the necessary measures to redress bad application, with the possibility to bring an action to the Court of Justice as last resort;

\footnotetext{
${ }^{27}$ This is reflected in Article I-1 Establishment of the Union of the Constitution for Europe of 2004, which states: [...] The Union shall coordinate the policies by which the Member States aim to achieve these objectives, and shall exercise on a Community basis the competences they confer on it. [...]"

${ }^{28}$ The European Council, which is he institutionalized meeting of Heads of state and governments of the member states has no formal decision making power under the present treaties.
} 
ii. a Council of Ministers representing the member states' governments; it is composed of ministers of member states who meet from time to time in order to take decisions upon proposal of the Commission, in three major ways:

- adopting the 'legislation' which is necessary to develop the common actions that are foreseen by the treaties - mainly directives and regulations;

○ taking decisions which are necessary for the functioning of the Community (for instance deciding on the level of tariffs as established in the common tariff, for the functioning of the customs union);

○ delegating decision making power to the Commission in policy fields which need daily management at central level; for instance decisions in order to stabilise sector markets in the field of agriculture;

iii. a Parliament representing the member state's citizens; it was composed of representatives of member state's parliaments during a first period (until 1979) and it is now directly elected for a five year legislature; it is endowed with three types of functions:

○ voting upon EC legislation proposed by the Commission and approved by the Council in those cases where the Parliament has a power of co-decision;

- controlling the Commission through classical parliamentary means - questions to Commissioners, enquiring Committees - or more recent ones like the European Ombudsman, in charge of controlling the good functioning of the Community administrations in the name of the European Parliament;

$\circ$ ensuring the accountability of the Commission through the possibility of adopting a motion of censure (by a majority of 2/3) which entails ending the Commission's functions before the end of the normal term ${ }^{29}$; 
iv. a Court of Justice ${ }^{30}$; it is composed of independent judges who are appointed for a fixed term and in charge of deciding upon:

- matters of interpretation of EC law (treaties and legislation);

- litigation between member states in the framework of the Community treaties;

- lawfulness of member states actions or abstentions as regards their obligations under EC law;

○ Lawfulness of the Community institutions' actions or abstentions.

Whatever the successes or failures of these four institutions, it would be a mistake to try and transplant them to other regional settings without understanding how they link with the Community method in which they are embedded. The Community method is made out of four elements, which are inseparable in order to understand the achievements of the EEC/EC/EU: pooling of sovereignties/powers/competences, the "Institutional triangle", functionalism and incremental evolution, and integration through law.

\subsection{Pooling of sovereignties/powers/competences}

Pooling of sovereignties/powers/competences is the European response to the issues of trying to work together at a regional level. As explained in Jean Monnet's Memoirs (Monnet, 1978), the idea of pooling has a pragmatic origin in the efforts of the Allies in coordinating the logistical aspects of bringing American troops to Europe during World Wars I and II. Jean

\footnotetext{
${ }^{29}$ This has never happened, but in 1999 the Commission led by Jacques Santer withdrew in order to avoid such a vote.

${ }^{30}$ Since the Treaty of Maastricht of 1992, the Court comprises a Court of First Instance (CFI) and the European Court of Justice (ECJ) itself. The Treaty of Nice of 2000 has opened the possibility of setting up other first instance courts, called chambers. The reason for these reforms was the overload of the ECJ, both a sign of the success of the Court and the confidence in its powers, and of the difficulties of the enterprise of regional integration.
} 
Monnet, who is known as one of the founding fathers ${ }^{31}$ of the European communities, had experienced both the virtues pragmatic cooperation at operational levels for these logistical problems, and the dead-ends resulting from governments' insistence on formal sovereignty in the framework of the League of Nations - the predecessor of the United Nations between World Wars I and II. The Community method as set up in the early nineteen fifties is a direct result of the comparison between both experiences: Jean Monnet and his team tried to transpose to regional integration the methods they had experienced with success in Allied logistics coordination. One of the politically/psychologically important aspects of these experiences was to try and avoid as much as possible the issues of sovereignty and instead always work bottom up from the needs of pragmatic solutions to practical problems.

The European Coal and Steel Community, established by the Treaty of Paris of 1951, was based upon pooling together natural resources (coal and steel) which were considered at the time as the major assets for industrial development. The notion of pooling meant that in theory each country remained the owner of its own resources, but that they established a management mechanism involving the six governments, albeit through an autonomous institution separate from these governments - the High Authority - which was in charge of regulating the very specific coal and steel market. This High Authority was an attempt to transpose at a regional level the model of regulatory agencies which existed since the end of the nineteenth century at federal level in the United States: both the mechanisms imagined in order to ensure the High Authority's independence and the type of regulatory powers it enjoyed in adjudication and rule making clearly recall this American experience ${ }^{32}$.

With the EEC treaty of 1957, this very tangible type of pooling of resources was later on extended to the far more defuse elements which are considered as the basis of market economy: labour and capital on the side of inputs, goods and services on the side of outputs. The idea of pooling resources and products/services was accompanied by the same idea of a shared set of institutions and mechanisms, both in order to set up the common market - by abolishing barriers to movement of these inputs and outputs - , and to managing the common

\footnotetext{
${ }^{31}$ With the German Chancellor Konrad Adenauer, the Italian Prime Minister Alcide de Gasperi, the French Foreign Minister Robert Schuman and the Belgian Prime Minister Paul-Henri Spaak.

32 Jean Monnet, who was the main inspirer of the ECSC Treaty, had established strong ties with prominent members of the US federal government during both World Wars, and this is probably one of the reasons which explain the import of the US autonomous agency model.
} 
market once set up - as it was clear to the founding fathers that markets need sophisticated forms of regulation in order to function, both because of the recurrent temptations of governments to restore protectionism, and because market failures have to be corrected by regulatory intervention.

From this very practice-oriented idea of pooling resources and outputs, the founding fathers of European integration have derived a more abstract concept of pooling sovereignties, which may be found for instance in the famous Schuman Declaration of 9 May 1951 - drafted by Jean Monnet and his staff - by which the French minister of foreign affairs invited the German government and other European governments to start the experience of the ECSC. The idea of pooling has an important symbolic value, because it implies that sovereignty is not lost, but simply shared, and thus nation-states remain while cooperating together.

\subsection{The 'Institutional triangle'}

The notion of 'Institutional triangle' which is typical of the Community method, includes a static element - three institutions involved in policy-making - and a dynamic element - a specific decision-making procedure. There have been evolutions in both the static and the dynamic element, but the basic design has remained unchanged since it was first conceived in the framework of establishing the ECSC in 1951.

\subsubsection{Three institutions}

The notion of 'Institutional triangle' is due to presence in the Community model of three institutions - the Parliament, the Council and the Commission - exercising the functions usually devolved to two institutions in national settings - Parliament and Government ${ }^{33}$.

The design of the Community institutions represents a mix between the agency model which has served for the establishing of some international organisations of a very technical nature - such as the Universal Postal Union for instance - , and the democratic model, which has been typically used for regional organisations such as the Council of Europe, or the

\footnotetext{
${ }^{33}$ The fact that in many countries Parliaments are made of two houses does not change the analysis, nor the differences between so-called presidential systems, where the Head of State is in charge of the executive function and parliamentary systems, where the executive function is distinct from that of Head of State, and exercised by a collegial authority presided by a Prime Minister or President of the Council of Ministers.
} 
Organisation of American States. The agency model is linked to the idea that legitimacy lies in expertise and is therefore seeking to represent in its institutions the technical expertise needed for a good functioning of the relevant policy field, while acknowledging the fact that the members of the organisation are sovereign states through a representation of their governments. The democratic model is giving more weight to political legitimacy and thus tries to represent both governments - who represent the national interests of member states and parliaments - who represent the peoples of the member states.

The agency model of the Community, which has first been used for the design of the ECSC institutions, has also heavily been influenced by the French concept of "administration de mission" - small structures established for the accomplishment of a specific cross-sector function, like the Commissariat général au plan, and the $S G C I^{34}$, which had been established soon after World-War II. This model clearly has some links with the model of US federal autonomous agencies, which were know to the entourage of Jean-Monnet, who was Commissaire général au plan when he elaborated the project of the ECSC. A High Authority of the Ruhr ${ }^{35}$ had been established by the Western Allies in Germany after World-War II in order to control the German coal and steel industry, and it was a point of departure for the design of the High Authority of the ECSC.

The mix of the agency model and of the democratic model explains the existence of three institutions in the Community method:

○ the Council (of ministers) composed of representatives of the member states' governments, who are members of their national executives ; this enables a direct influence of member states governments in the Community institutions;

○ the Parliament, which was composed of members of national parliaments until 1979, but for which the EEC treaty already foresaw in 1957 the possibility of a

\footnotetext{
${ }^{34}$ Secrétariat général du Comité interministériel pour les questions de coopération économique européenne. This agency, which had been established in 1948 in order to coordinate French governmental policies in the framework of the OECE which became later the OECD, is in charge of coordinating French positions in the framework of the EU Council of Ministers and of monitoring the implementation of EU/EC policies by French public administrations.

${ }^{35}$ The Ruhr is the main mining and steel producing region of Germany.
} 
direct election; the decision to have a directly elected Parliament instead of a representation of national parliaments was taken in 1977 by the Heads of State and governments of the nine EC member states with the aim of fostering democratic legitimacy - but the fact that national parliaments were not any more represented in the EC institutions seems to have increased the problems of accountability often referred to under the slogan of 'democratic deficit' of the EC/EU;

○ the Commission (called High Authority in the ECSC), an independent agency to a certain extent based on technical expertise, with the duty to foster common European interests; its members are appointed by governments, but for a fixed term and without possibility of recall, and they have their own administrative infrastructure, in order to guarantee effectively their separation from individual member states' administrations and interests.

There has been changes overtime in the composition of these institutions. The numbers of Commissioners, the length of their mandate, the procedure for their appointment have varied. The composition of the Council has changed too, with the possibility added overtime for ministers of regional governments to represent their country instead of national government members. The mode of selection of the Parliament has also changed, not only from members of national parliaments to directly elected members, but also in their mode of election. These are elements of flexibility with a constant setting of three major institutions. Rather than going into the details of the composition of each of these institutions, a reflection on the adaptation of such a general setting and the possibilities offered by flexibility is probably what could be of interest to other experiences of regional integration.

\subsubsection{A joint decision making procedure}

The dynamic element of the Community method is its joint decision making procedure. It has been designed in view of ensuring that the three institutions would have an appropriate share in policy decisions, and especially in the adoption of the necessary legislation (directives, regulations and decisions, in the technical jargon of EC law). In this perspective the Community method is based upon three elements. 
- As a matter of principles, decisions are shared between the institutions, in order to ascertain that the different legitimacies are taken into account when coming to a joint decision. None of the three major institutions can decide on its own. Initially the idea was mainly to ensure that the political priorities of member states protecting sovereignty and promoting national interests - could not prevail upon the technically sound proposals and the general interest common to the member states. In Jean Monnet's idea the ECSC Council of Ministers would mainly have to agree to the proposals of the High Authority or reject them. Time passing it appeared that things were more complicated. The Council could not be constrained to simply take it or leave it, as member states would not accept to sacrifice some of their national interests without clear counterparts: this has lead to a development of intergovernmental bargaining on the basis of the Commission proposals, leading to compromises which are usually the result of a common work of the Commission and of the member state which is presiding over Council meetings at decision making phase. Growing concern for democratic accountability has led to extend the powers of the Parliament from mere consultation to a vetoing power in a growing number of fields - by means of the so-called 'co-decision' procedure, according to which a proposal of the Commission needs to be agreed upon by both the Council and the Parliament.

- A second major feature of decision making under the Community method is that the Commission is the sole institution that may formally take an initiative - usually resulting in a normative text of legal value, regulation, directive or decision. Technically this happens through the use of three mechanisms:

- the Council may only discuss on the basis of a proposal that has been formally put on the table by the Commission;

- the Commission has the right to withdraw its proposal at any moment - if it thinks that there is a risk that the final decision will not be geared towards the common interest, but simply be an aggregate of separate national interests; 
- in the fields where Council decisions are being taken by majority vote, a majority vote may only confirm a Commission proposal; if the Council wants to modify the Commission's proposal it needs to do so by unanimous vote, and the Commission still has the power to withdraw its proposal - if it feels the decision taken by unanimous vote is against common interest.

- A third element, which is often presented as inherent to the Community method, but which is not always necessarily present, is the idea that the Council - representing member states - acts by qualified majority voting, a system which allows to take into account both the principle of sovereign equality of member states, and a realistic weighting of each state's political and economic importance. The principle of majority voting is mainly intended to avoid that a single government takes the others in hostage by vetoing a decision.

The mechanism of qualified majority is far more complex in that it tries and reconciles two very opposed principles. In the perspective of other experiences in regional integration it would be wrong to insist too much on majority voting, as has been done in the European context in the last decades and especially during the preparation of the treaty establishing a Constitution for Europe. Practice shows that majority voting only works once confidence has been established between participants in the system. European experience with the so-called Luxembourg compromise, which basically consisted in deferring from 1970 to 1987 the application of majority voting mechanisms that had been foreseen in the EEC treaty, confirms this view.

Since 1987, although majority voting is available in theory, the Council most often decides on a consensus base. This shows that the detailed mechanisms of majority voting - which attract a lot of attention from politicians and the press in phases of treaty reform - are not that important in practice. What matters it that the possibility of a decision being taken by majority voting: this pushes all governments to 
participate in the negotiations which follow the presentation of a Commission proposal, for fear of being left out of the final decision.

Here again, as it already was the case for the static element of the notion of 'institutional triangle', it is hardly relevant for other experiences of regional integration to examine the details of the Community decision making procedures and their evolution. Far more important is a reflection upon the ideas, concepts and strategies which have led to the adoption of those types of mechanisms. One should also think about the major constant features of the mechanism - in the European context, it is the involvement of the three institutions and the gatekeeper's role of the Commission - while reflecting about the possibilities offered by flexibility but also the limits to flexibility which are necessary in order to keep the system working and progressing.

\subsection{Functionalism and incremental evolution}

Strictly speaking 'functionalism' and 'neo-functionalism' are academic concepts, used as explanatory tools in the theory of international relations. 'Neo-functionalism' more specifically applies to European integration in the theoretical reconstruction of Ernst Haas (Haas, $1958 \S 1964)$.

In practice as already mentioned, the approach to integration of the political founding fathers of the ECSC, and especially Jean Monnet and his team, was not overtly based upon a theoretical conceptualisation of international relations. Some members of Monnet's team might have been influenced by functionalist theories of international relations, which existed at that time in the United Sates; but they were certainly much more influenced by the experience that Monnet had acquired in coordinating transatlantic Allied logistics during World Wars I and II. In this context, it makes little sense to distinguish between 'functionalism' and 'neofunctionalism': the main idea is that this approach of regional integration - under the motto or the Unite States of Europe in the early fifties - is based upon the common exercise of a number of clearly defined functions, as opposed to the constitutional approach which led to the construction of the United States of America by the adoption of a constitution and the creation

of institutions. According to an old French saying ("la fonction crée l'organe") institutions are 
the consequence of a choice of policy functions to be exercised: their design does not precede the allocation of specific sector powers.

The functionalist idea appear at the forefront of the famous "Schuman declaration", the speech by which on 9 may 1950 the French minister of Foreign affairs Robert Schuman formally invited Germany and other European countries to engage into the project of the pooling of their coal and steel resources into what would become the ECSC. The speech had been written by Jean Monnet's team, and contains a very clear statement of the functionalist approach: "Europe will not be made all at once, or according to a single plan. It will be built through concrete achievements which first create a de facto solidarity." 36 The idea was to apply a step by step method rather than starting with a grand project which would either foster too much resistance or be criticized as too costly and unrealistic.

The functionalist and neo-functionalist theories are mainly based on the idea that integration between sovereign states can be achieved through creating common interests in specific sectors, which result in de facto solidarities. A central feature of neo-functionalism is the idea of spill-over, i.e. that integration in one sector has consequences on another sector, creating thus a demand for more integration. One of the best recent illustration of neofunctionalism in action is the series of links that the European Commission established successfully under the chairmanship of Jacques Delors from 1985 to 1995: by first endeavouring to achieve the internal market in order to later establish a monetary union, the latter creating then the need for a solid political counterpart to the powerful common central bank. His example however shows also the limitations of the neo-functionalist approach, which cannot force a government to abandon what is sees as being at the core of sovereignty if it does not want to: it has been the case of the UK and Denmark, whose governments agreed to the Maastricht treaty only because they were exempted from automatic participation in the monetary union.

The functionalist approach, a pragmatic approach based on sector interests - as opposed to ideological approaches based upon an artificial will of achieving political integration - has been a key reason for the successes of European integration and might prove very appealing as 
a method for regional integration elsewhere. Experts in governments, intergovernmental organisations and academia may most probably gain from revisiting the neo-functionalist theory in the perspective of other regions than Europe, taking into account for instance the impact of major asymmetries upon the whole model of international relationships it is supposed to describe. Beyond experts, decision makers would certainly benefit from understanding this approach on the basis of the experience of their European counterparts, and discussing to what extent it may be taken over and adapted to other economic and political contexts.

\subsection{Integration through law}

A last and prominent element of the Community method is that integration is achieved through a series of very specific legal tools. From the outset, it was clear to the promoters of the project - and not only to the legal experts who drafted the clauses of the treaties of Paris and Rome - that the role of law would not be limited to the framework of treaties establishing the Communities. Both practitioners who had experienced the functioning of the League of Nations (Jean Monnet once again) and lawyers who had reflected upon the limitations of international law - especially with the experience of the Permanent Court of International Justice (PCIJ) which had been established after World War I by the Versailles Peace conference - were convinced that a very solid legal basis was needed for the experiment to succeed. This has however to be related to a set of countries which had a strong tradition in solid legal institutions since about two centuries. Three major sets of ideas are at the root of the Community method of integration through law, whose success has to be related to the strength of legal professions in the member sates.

\subsubsection{Directly applicable law}

In the framework of international intergovernmental organisations, written legal rules take the form of multilateral treaties, conventions, protocols etc. - this is true for global organisations like the organisations of the UN system or the WTO, or regional ones like the Council of Europe or the Organisation of American States. Two major features of these agreements are, first the principle that states can only be bound by treaties if they formally accept to do so, by signature or ratification, and second, that their obligations are closely

${ }^{36}$ «l'Europe ne se fera pas d'un coup et dans une construction d'ensemble : elle se fera par des réalisations 
linked to the principle of reciprocity - if one party does not respect its treaty obligations, the other does not need to comply with her own ones any more.

The consequence of applying classical instruments of international law is a high degree of uncertainty due to a series of factors:

- the executive of a country may well negotiate and sign a treaty, protocol, convention, etc., but not be authorized by another institution (usually parliament) to bind itself through ratification; this happened with the United States when President Wilson - who was one of the main promoters of the post World-War I peace settlement - failed to get the US Senate's approval to ratify the treaty of Versailles and the attached status of the League of Nations;

- under international law, and unless provided differently by a specific treaty, states may emit reservations at the time of signing or ratifying a treaty, thus accepting to be bound by some clauses only and not by others;

- if one party to the treaty does not comply with its treaty obligations, the other parties may also refuse to apply these clauses in their relations with the reluctant country, etc.

The drafters of the Paris and Rome treaties were very aware of these limitations which were considered as major sources of the failure of the League of Nations. Furthermore, they were convinced for technical and economic reasons that the mere idea of a common market, even limited to a specific sector like the ECSC, was not compatible with a system of rules which would not be binding in the same way for all member states and at the same moment. On the other hand, their aim was not to set up a federal state, with a parliament or Congress endowed to adopt laws. This is how the tools of EC regulations and directives (this is the jargon of the Treaties of Rome and still is the wording of the EC Treaty) were invented. These instruments enabled to have legal instruments which are binding for all member states once adopted by the Community institutions, without further need for ratification and without any effect of the principle of reciprocity. The difference 
between these two instruments is that regulations are applicable as such, whereas directives need to be 'translated' into more detailed national laws and regulations, because they are only setting common objectives while respecting differences between member states, such as the fact that some already have laws and regulations which correspond to the objectives and content of the directive and others not.

The major characteristic of this system is that even though parliaments and executives often need to adopt complementary national laws and regulations in order to give all their effects to Community legislation, they are not allowed to refuse to implement them and they are bound by deadlines for the adoption of the necessary tools. In practice, delays and reluctance to comply sometimes lead to the fact that more time is needed for a Community legislation to be really applied throughout the Community. The judicial and quasi-judicial mechanisms for enforcement ensure that an overwhelming lot of the common legislation is indeed applied throughout the entire Community.

\subsubsection{Enforcement mechanisms not relying on reciprocity}

As mentioned before, international law heavily relies upon reciprocity for its effectiveness. This is due to the fact that the internal mechanisms which rely eventually upon the possibility of the State institutions using force are not available for international institutions. Indeed the usual sanctions of international agreements are the possibility to stop applying clauses that are not being respected, and to adopt reprisals and countermeasures of different possible forms. Typically internationally responsibility is very different in its functioning from national systems of tort law, where courts can rely upon state institutions in order to force compliance if necessary. One of the major consequences of reciprocity is that international courts are not considered as a normal tool to settle international litigation, both because of the lack of sanctions for their decisions and because going to court is usually considered as a rather unfriendly step by the relevant governments. In combination with the principle of state sovereignty, this has also led to condition the possibility of going to court against a given state to its previous acceptance - in the specific litigation itself, as happens also with arbitration - or on the basis of a more general ex-ante but still explicit acceptance - as in the system of facultative acceptance of the competence of the ICJ. 
Here again the drafters of the EC treaties were conscious of the limitations of the PCIJ between World Wars I and II and of the need to have common rules enforced in all member states in order to have a functioning common market. Hence the two major features of the European Court of Justice and the procedure to initiate proceedings against member states.

- The EC treaties do not accept any possibility of reservations, and accepting to become a member of the EC includes the acceptance of the ECJ's competence in litigations relating to the interpretation and application of EC law, and the commitment to obey its rulings. The system is not working perfectly, as indicated by the fact that the Maastricht treaty introduced the possibility of a fine against a member state who does not comply with a Court ruling. However, the proportion of non applied rulings remains extremely low, and if there are delays or difficulties in the application of certain rulings, governments do not oppose the court's power, and they show concern about being considered as the 'bad pupils in the classroom' which would damage their reputation and moreover reduce their bargaining power in future decision making. As we will see later, this can only be understood in taking into account the solid presence of legal professions in all member states.

- The second main feature of the ECJ system is that access to court is not limited to the states, contrary to the classical case of international courts. A first and very important mechanism is the fact that the Commission has always the possibility to initiate court proceedings against a member state - usually after a non judicial phase which gives it the possibility to come to a negotiated agreement with the government which is accused of non-compliance with its treaty obligations. As a matter of fact, there have been only two cases since the beginning of the Communities where the government of a member state initiated such proceedings against another member state - as against hundreds of proceedings which are initiated by the Commission or other plaintiffs each year. As ensuring compliance with the treaties and EC law is one of the three main functions of the Commission, it is far better placed than a government to start proceedings: if it does so, there will not be interferences with bilateral diplomatic relationships. Furthermore, the 
Commission is well placed as an independent organisation to receive complaints from the potential beneficiaries of EC law, which might be more reluctant to turn to their own government to ask them to initiate such proceedings.

Furthermore, the treaties provide for the possibilities of individuals to start proceedings against EC institutions if there interests are directly touched upon by EC decisions. They may not proceed directly against member states who do not comply with Community law, but one should not forget that the Council is composed of representatives of the member states. There is even a possibility for individuals to go to Court in case of inaction of the Institutions, thus obliging them to come to some kind of agreement upon implementing the obligations they have subscribed to in the treaties.

There is no need for non experts and certainly non lawyers to go into the subtleties of the different court actions which are set up by the treaties and to what extent they have been refined by a very developed case law of the ECJ. This is not necessary in order to understand the impact of the ECJ on the functioning of regional integration in Europe. On the contrary, a number of lawyers might well forget about these guiding principles and thus recommend mere copies of the clauses of the EC treaties without understanding how the fit in the general system of the Community method. Indeed most of the technicalities of court actions only make sense in this general context.

\subsubsection{A network of Courts}

The EEC treaty has been especially innovative with one very specific procedural tool, which was proposed by the Italian delegation during the negotiations. The proposal was based on the very recent experience of this country with its new Constitutional Court. This was the system of questions for preliminary rulings, which may be addressed by any national court to the ECJ in order to ask its decision on how the treaties or a piece of EC legislation have to be applied, or whether EC legislation has been adopted by EC institutions in conformity with the treaties. Through this mechanism, any affected individual may eventually bring to the court's attention a 
problem of application of EC law where his interests are being affected. This mechanism has had two consequences.

- First, the effectiveness of ECJ preliminary rulings benefits from the national systems set up for the enforcement of national courts' rulings. At the end of the day, it is the national court who decides to apply the interpretation which has been given by the ECJ. As a consequence there is no discrepancy in a given country between the effectiveness of national law and the effectiveness of EC law. This works because national courts recognise the ECJ's authority on the matters it knows far better than national courts and thus follows the content of its rulings.

- Second, this mechanism is a very useful complement to actions for infringement against member states, which can only be initiated by the Commission of by another member state. Formally speaking, a national court cannot ask the ECJ to rule that a piece of national legislation is an infringement to EC law. But in practice, the ECJ will explain how EC law has to interpret the parameters which are to be applied for its correct application. If national laws or regulations are contrary to these parameters, the national court will have to ensure the correct application of EC law, if necessary by not applying the national law to that case. Here again national courts follow the ECJ rulings on the basis of professional persuasion.

Once again when it comes to other systems of regional integration, a mere reproduction of the relevant treaty provisions or even of the Statute of the ECJ, which is a protocol annexed to the EC/EU treaties, might be an illusion. The system is certainly not perfect and some of its problems may stem from the treaty or statute provisions themselves. However what makes it work is not the wording of the treaties, but the fact that the system has been conceived by professionals from the member states and embedded in the Western European legal systems, where the effectiveness of law benefits from a long tradition of legal professions which not only have the necessary technical skills but are also an important part of the formal set-up of state and society institutions. 


\subsubsection{Legal professions as stakeholders of integration}

In view of other experiences of regional integration - including NAFTA - it seems that this highly important feature of the Community method, i.e. integration through law, might be one of the most difficult to reproduce. Its success is indeed based upon a highly developed system of courts composed of independent judges and relying on a very expert legal profession. There are big differences in the organisation of courts and legal professions from one member state to the other, but they all have in common a strong tradition - sometimes recent, as in the case of countries like Spain or Portugal, where the independence of judges only came with democracy. The effectiveness of the European countries' legal systems is far from being perfect, and differs very much from one country to another, but it is on the whole quite strong. It also relies upon a series of specific elements of judicial procedures within member states, which have taken a very long time to establish. In view of comparisons it has to be underlined that in practice, the legal culture of most member States of the European Union be it based on English type common law, on French type codified civil law and judge made administrative law or on German-Italian type codified civil law and partly judge made constitutional law (Spain, for instance being influenced by both) - is far less formalistic than it is perceived by non-specialists, and probably far closer to Canadian and US-legal cultures than to those of Latin America.

The importance of judge-made law is especially striking when considering the development of EC law. ECJ judges use the same kind of techniques that have been developed by their counterparts in the Constitutional courts of a number of member states, or also of some supreme courts like the French Conseil d'Etat (the country's supreme administrative court). These rely both upon technical skills of very solidly educated lawyers and upon a high degree of administrative and political sensitivity, which usually allows them to avoid taking decisions which would encounter too strong resistance by an important number of member state's governments ${ }^{37}$.

Two major principles - amongst many others which are not as interesting to non specialists - have been developed by the ECJ while not being explicitly present in the treaties: the principles of direct effect and primacy of Community law. In a nutshell, the principle of 
direct effect allows individuals to ask for the benefit of Community law and especially of some of the most important principles embedded in the treaties, like the free movement of goods, persons, services and capital without the need for specific national legislation which would take up these principles. The principle of primacy means that whenever national law differs from a rule or principle of EC law, EC law has to be applied and national law put aside by the courts and public administrations. The technicalities and conditions needed for the application of these two principles cannot be understood without some solid legal education. What is important and easy to submit, is that these two principles have enabled to give the means to the interested businesses and individuals - with the help of the legal professions - to play a growing role within all member states in order to make sure that EC law would not remain mere declarations of intent.

It would be wrong to think that this network of courts is only a watchdog of national governments' compliance with treaty obligations and of effective implementation of EC laws and policies in the member states. The ECJ has played a major role in deepening integration, especially during the seventies and up to the mid-eighties, when decision making in the Council was extremely slow due to the very reluctant attitude of member states that had a de facto vetoing power in all fields. This happened especially through giving direct effect to treaty provisions against diverging national law, sometimes revealing and sometimes creating gaps in the regulatory systems and thus fostering substantive action of national and EC institutions in order to make the EC function.

It is also necessary to insist upon the fact that the importance of EC law has gradually grown beyond the very technical sectors where it started to a broader set of fields. Due to the very technical content of most of its rulings, it managed to gain enough respect from EC and national institutions as well as in the legal professions of member states, including academia, in order to be protected against political attacks when it rulings started to collide with strong national interested.

The role of law in European integration shows clearly the difficulties in trying to export the EC model without taking into account the entire Community method. Other experiences of

${ }^{37}$ One of the favorite techniques of these courts is to establish principles in cases where they do not lead to 
regional integration often do not establish an independent judicial review system, or they only establish a limited system following the classical patterns of international justice. The EC system would probably not have achieved much without an effective role for law, but on the other hand, any recommendation to take over specific institutions or procedural tools or even the entire system of Community law might be an illusion if there is not a sufficiently developed judiciary and legal profession in all the concerned countries. The only solution is to constantly keep in mind the different elements which make a system work and keep enough flexibility to adapt to different settings in time and space.

\subsection{Community method v. intergovernmental method?}

The Community method has been at the heart of EC integration since the beginning, i.e. since the Schuman Declaration of May 1950. It is the most genuinely European contribution to the governance of regional integration, and it is necessary to understand how it has allowed to start and to progressively build up what has become the European Union. This does not mean that the entire development of European integration follows the path of the Community method, its institutions and procedures.

Since the nineteen sixties, a second path of integration has been followed, essentially in the field of political cooperation in foreign affairs and defence: the intergovernmental method, which relies heavily upon direct cooperation between national governments. Even Jean Monnet admitted that a strong input of the national executives was indispensable to keep the momentum of integration and to open further fields to common policies, and therefore recommended the institutionalisation of top-level meetings between the Heads of member state executives, which became the European Council. The Single European Act of 1986 and the Maastricht treaty of 1992 further institutionalised the intergovernmental method in new fields of cooperation. The 'Lisbon Strategy' went even further in using the intergovernmental approach for new developments in proposing the so-called Open Method of Coordination (see Section 4). There are at least two reasons which explain this use of the intergovernmental instead of the Community method:

condemn a state, and use these principles against states only later, once they are generally recognised. 
- there are still policy fields where member states feel that they need to retain ultimate choice, and they feel that the Community method deprives them from this possibility, and

- there are doubts about the capacity of the European Commission to handle these new fields with sufficient expertise.

This being said it has to be stressed that there has never been a step backwards from the use of the Community to the intergovernmental method in a specific field. On the contrary, the tendency has always been to apply the Community method to fields which have been first tested under the intergovernmental method: this is especially clear with the Amsterdam and Nice Treaty which provided for the so-called 'communtarising' of important aspects of internal affairs which had started with the intergovernmental method in the framework of the Treaty of Maastricht. The Constitution for Europe of 2004 represents a further example of this tendency.

In the case of monetary Union, specific new institutions have been set up, which may be considered as a sector variation of the Community method, or as a sui-generis case, but certainly not as a form of the intergovernmental method. As a matter of fact the source of inspiration for both the System of European Central Banks and the European Central Bank itself has been the German and US experiences in central banks. 


\section{Regional Integration as a 'multilevel' Issue}

Political science literature on European integration is using since a number of years the expressions 'multilevel government' or 'multilevel governance' in all possible ways, sometimes 'ad nauseam', and so does more recently legal literature. Dispute on definitions and concepts might go on indefinitely in this field, and have little practical value. What is of practical importance is that the expression 'multilevel' relates to a very important phenomenon, well known not only to academics specialised in European studies, but also to a number of practitioners. Regional integration can only develop through a simultaneous and related functioning of at least two 'levels' of governance: the specific regional institutions and decision making procedures on one side, and the different institutions and procedures of governance of the member states on the other side. If national institutions and public administrations are not fit for the coordination of policy making at regional level, and if they are not able to translate the decisions which are taken at regional level in street level practice, the integration process will remain extremely fragile if not hollow, and might collapse with the first crisis between member states.

In the case of Europe, most member states have also strong local authorities - at communal level and at the level of so-called provinces or departments - and sometimes strong 'sub central authorities' which are called regions (Belgium, France, Italy, Portugal), countries

(Länder in Austria and Germany) or communities (Belgium again ${ }^{38}$, and Spain), which are sometimes considered as non sovereign states, as in the USA. This is why the term multi-level is better fit than the expression 'two-level' government would be.

A very important feature of European integration is that as a matter of principle, the implementation of common policies is being carried out by the institutions and public administrations of the member states - very rarely by the European institutions themselves. This means not only that the effectiveness of common policies relies almost entirely on the capacities, resources, skills and good will of member states institutions and public administrations, it also means that the feasibility and legitimacy of common policies depends 
upon a strong involvement of all levels of government in regional decision making. This is a challenge which Europe has not yet been able to face comprehensively especially when it comes to institutional reform and management.

\subsection{Implementation and multilevel governance}

For a very long time, there has been a lack of focus on the effective implementation of community policies: the European Commission mainly monitored the formal transposition of directives in national laws and regulations, without trying to have a comprehensive view of the extent to which laws and regulations were being applied in the member states. There was only a piecemeal control over overt cases of non compliance that were brought to the attention of the Commission by way of complaints of individuals and businesses, or to the European Court of Justice by way of questions for preliminary ruling from national courts. There were at least three reasons for this: clearly the European commission did not have the resources to undertake a comprehensive monitoring of compliance to the treaty provisions and Community legislation; its political weight was not important enough to allow it to enquire into the functioning of national administrations and institutions if there were no clear cases of violation of Community law; but a third reason was that many institutions and public administrations did have a culture of legal formalism which they transplanted into the European Commission staff. The problem is that legal formalism may be the visible part of a solid and well-functioning bureaucracy, as in the German tradition, or on the contrary only a façade that hides inefficient bureaucracies and render them even heavier.

The change has come only in the mid nineteen nineties.

- First, the European Commission started to integrate the idea that it was not sufficient to establish the legal framework for the internal market, but that the internal market had to be at least monitored if not regulated. This was requiring far more action at national level, and thus could change the nature of the work of the Commission itself. The Commission had been designed and had functioned during decades as an institution whose main role was to draft legislation on the one side, while prosecuting those governments which did not comply with common legislation on the other.

\footnotetext{
${ }^{38}$ In Belgium there are two sets of sub-central authorities, communities have powers in the cultural, educational
} 
- Second, the European Commission started also acting with a different set of tools in order to ensure cooperation between different public actors - and sometimes private actors -, a far more demanding job in terms of the skills necessary for effective functioning of its agents.

At the same time, the prospect of enlargement to countries which did not have a fully fledged market economy forced the Commission to take into account the effective capacity of implementation of common rules and policies and not only the formal transposition of legal rules. The association agreements with candidate countries of Central and Eastern Europe contained specific clauses, which foresaw a monitoring mechanism, by which the Commission administration would cooperate with the authorities of these countries in assessing progress made in setting up the necessary institutions and procedures for the implementation of the 'acquis communautaire'.

These processes have not been conducted in a perfect way and it is still too early to assess their successes and failures, but they might be very interesting and relevant for other experiences of regional integration.

\subsection{Multilevel governance and legitimacy}

Since more than two decades, European governance issues are being identified by politicians and to some extent in literature with the so-called 'democratic deficit' of the European Union. EU Institutions are being considered as too technocratic, driven by experts and public administration rather than by elected representatives. These critics may also be addressed to a number of national governments, but they are expressed in a stronger manner in the case of European institutions. There are two explanations for this: first there is the habit of many politicians who prefer to scapegoat European institutions rather than to endorse full responsibility for policy choices which are not easily accepted by the people, and second there is no direct link between the election of the European Parliament and the composition and policy preferences of the European Commissioners. This second aspect has as a consequence a

and social fields, and regions have powers in the fields of economy and infrastructures. 
very low turnout in the elections to the European Parliament, which in turn is somewhat depriving members of European Parliament from a solid political legitimacy.

It would probably be more accurate to identify the 'democratic deficit' as a 'deficit in legitimacy and accountability' of the European Union, and sometimes as a 'deficit in communication'. The idea of a 'democratic deficit' of the Union is not only a simplistic slogan; it disregards the multilevel nature of European governance. Legitimacy and accountability in regional integration cannot be pursued only at one level - European or national - but need to be addressed at all relevant levels at the same time. The European experience not only shows that there is no easy solution to these type of issues, which have been at the centre of the European Commission's "White book on European governance" of 2000, but also that any isolated attempt at solving the question by institutional engineering at the European level is deemed to fail.

\subsection{Multilevel governance and institutional reform}

The issue of multilevel governance is often overlooked by those in charge of designing systems of governance for regional integration and of making them work. The case of institutional reform in the EC/EU process of dynamic developments has for a long time illustrated this lack of attention to the issues of multilevel governance at home. There are two rather simple reasons for this lack of attention. First, the most important elements of institutional reform are usually proposed in the framework of the intergovernmental conferences which amend the EC/EU treaties, and thus focus on the content of the treaties which are only concerned with the regional institutions. Second, the national aspects of governance - and the local or sub-central aspects - are deemed to be in the sole realm of each

member state, not a matter of common concern, due to the traditional diplomatic principle of non interference in internal affairs. The momentum for reform which is gained during the treaty amendment procedure very often gets lost once ratification is acquired. A number of politicians and practitioners at both supranational level and national level (or even at subnational level) seem to consider that in order to progress on governance issues in European integration, it is sufficient to concentrate on European institutions and procedures, and that member states will do the necessary to ensure that common policies are implemented in the 
best possible way. The European experience is not satisfactory in this respect indeed. A number of interesting lessons may be drawn from this unsatisfactory experience, which translate both in terms of institutional design (understood as the establishment of institutions and procedures) and in terms of training of the relevant actors. Taking seriously the idea of multilevel governance means that at least three aspects have to be considered.

Experience in the EC/EU as a whole and experience at Member States' level both show that the system of governance of regional integration needs constant adaptation, in order to respond to the dynamism of the integration process. Adaptations have to be undertaken both at the level of European Institutions and at Member state level. Each set of adaptations has to take into account both the existing structures and procedures at the other level, and the changes they will undergo. The founding treaties, or the specific European sector legislation, may be perfectly designed from an expert point of view, but they are in danger of remaining mere blueprints if the necessary corresponding structural and procedural adaptations are not being made in the member states, in political institutions as well as public administration. Adopting the national legislation which is needed for the implementation of a common policy is a necessary element, but it is far from being sufficient. In order for new policies or amendments to already existing legislation to be implemented and enforced in due time, in good faith, and efficiently, a number of arrangements have to be made, resources to be reallocated and priorities to be set.

Amongst the many issues at stake, there is a strong link between a careful ex-ante expression of a given national position in European decision making and the smooth ex-post implementation of the relevant legislation or decision. This is the best illustration of this issue of multi-level government. It is common knowledge in European institutions that the British or the Danish governments, which show rather little enthusiasm towards the idea that integration and common action would be necessarily better than isolated national actions, are demonstrating very good performances in applying common policies, even if they do not correspond to the optimum of their wishes. This might be explained to a certain extent by a specific culture in law-obedience, but it does not account for the fact that far more euroenthusiastic governments of countries which share the same type of culture score worse when it comes to implementation. Case studies show that systems of coordination and for voicing 
organised interests in due time are at least as important if not more than "culture" which might be very ill-defined.

This element to my view is extremely important in order to counteract hasty judgements that tend to explain that Latin-American culture would not be adapted to institutions, procedures or structures which have been designed in Europe. Some member states, like France, Spain and the United Kingdom, have fairly powerful and sophisticated institutional settings for the coordination of their positions in European decision making, while others, like Germany or Belgium, traditionally had a far looser system. There is no reason to believe that one of these specific experiences might be a solution to recommend to countries of LatinAmerica or the Caribbean. As a matter of fact, with the increase of the number of EC/EU member states, the diversity of national systems is providing a growing number of relevant experiences, which may be as valuable if not even more, as the experience with European institutions at supranational level. What is needed is not to try and copy existing settings because they seem effective in a European country, but to understand what are the elements which explain that a setting is adapted both to the national institutions, procedures and administrative culture and to strengthening the integration process overall. 


\section{Key Issues and Proposed Solutions for European Governance at the time of Eastern enlargement and of the Constitution for Europe}

The three previous sections of this paper have been written in order to try and show what the most permanent features of European integration governance are. The present section will focus the key issues which are on the agenda of the European Union in this first decade of the XXIst century, and upon the solutions which are being more or less officially proposed to solve these issues. Some of these experiences might not be relevant to the more recent and less extended experiences of regional integration which are developing in Latin America and the Caribbean. Considering these contemporary issues and solutions might nevertheless be inspiring, because they contribute to the illustration of the features of European integration which have been addressed in the previous sections. Some issues might resemble those which are faced in the Americas, and some European solutions might seem appealing as such: they should be examined with care in the broader context before deciding whether they are really worthwhile transposing.

This final section tries to summarize the main present issues as they appear openly on the agenda of the EU, but also taking into account an issue which does not have the salience it should if all aspects of the governance of regional integration were to get the attention they deserve. Three key issues are on the agenda of the EC/EU: keeping an efficient and democratic system for decision making with an ever-growing number of Member States; enhancing coordination without creating a federal type of power allocation; differentiating integration according to policy fields. A fourth issue seems often to be overlooked by members of both the EU institutions and member states: addressing the management deficit of the EC/EU system in a context of continuous enlargement and deepening of European integration.

\subsection{Keeping an efficient and democratic system for decision making with an ever-growing number of Member States}

Since the enlargement of the European Communities to Spain and Portugal - which meant that the number of member States had doubled as compared with the initial period where 
the Community institutions were designed - concern has been raised as to the capability of the EC/EU institutions, and especially the Council and Commission, to work with mechanisms and procedures which had been designed for a far smaller and far more homogeneous group of countries. Concern about this has continuously grown, especially with the last enlargement to ten new member states, nine of which being medium or small sized countries.

Attention has often been focusing upon technicalities directly deriving from numbers. Until 1995 there was a total of no more then fifteen European Commissioners, a number fit for team-work and collegial decision making; keeping the same system would have meant having a total of 31 Commissioners from 2004 onwards. Discussions in the Council are based upon the principle that all ministers and the representative of the Commission should be able to explain their country's or institution's position: with an average of ten minutes speeches, this means that a "short meeting" of the Council with about three series of topics could last about three and a half hours until 1973, but would need thirteen hours in 2004 . Until 1973 there were three official languages, from 2004 onwards twenty-one: in order to ensure that the same law is applied in all member states, it is indispensable to have all legally binding texts (several thousands of pages of the official journal of the EU every year) translated in all official languages.

Furthermore the issue of democratic legitimacy has grown in relation to enlargement because of two factors: first the growing diversity of institutional cultures between member states, and second, the difficulties of acknowledging the different size of populations and reconciling it with the principle of equality between countries. Until 1973, there were three 'big' countries of about the same size (France, Germany and Italy), two medium sized countries (Belgium and the Netherlands), which together were the equivalent of about one third of a 'big' country, and one micro-state (Luxembourg), with a population of 1/120 of a 'big' country. In 2004 there are six 'big' countries - but Germany has 15 million more than France, Italy or the UK, and twice the size of Spain and Poland -; twelve medium sized countries, whose populations put together are smaller than that of two of the 'big' countries put together, and seven small states, amongst which three micro states - the total population of Cyprus, Luxembourg and Malta together is hardly bigger than that of Estonia, than $10 \%$ of the Netherlands, 2,5\% of France or $2 \%$ of Germany (see table 2). These issues have been one of 
the main concerns of the European Convention 2003-2004, which drafted the Treaty establishing a Constitution for Europe, signed on 29 October 2004 and which will enter into force on 1 November 2006 if it is ratified by the 25 member states.

Table 4: Governance reform in the Constitution for Europe

\begin{tabular}{|c|c|c|}
\hline Proposed solutions & Major elements of the proposed solution & Art.* \\
\hline $\begin{array}{l}\text { Enhancing } \\
\text { representative } \\
\text { democracy }\end{array}$ & $\begin{array}{l}\text { Increase of the powers of Parliament by a new legislative } \\
\text { procedure } \\
\text { Further extension of the policy fields where its consent to } \\
\text { legislation is necessary }\end{array}$ & $\begin{array}{l}\text { III-396 } \\
\text { passim }\end{array}$ \\
\hline $\begin{array}{l}\text { Enhancing } \\
\text { participative } \\
\text { democracy }\end{array}$ & $\begin{array}{l}\text { Consolidation of the mechanisms for involvement of } \\
\text { interest groups and NGO's } \\
\text { Creation of a new mechanism of 'popular initiative' to } \\
\text { enable citizens to require the Commission to present new } \\
\text { proposals for European legislation }\end{array}$ & $\begin{array}{l}\mathrm{I}-47 \text { and } \\
\mathrm{I}-48 \\
\mathrm{I}-47\end{array}$ \\
\hline $\begin{array}{l}\text { Reinforcing the } \\
\text { capabilities of Council } \\
\text { of Ministers }\end{array}$ & $\begin{array}{l}\text { New definition of majority voting in the council, taking } \\
\text { into account in the same way for all countries both the } \\
\text { size of their population and the principle of equality } \\
\text { between sovereign states } \\
\text { Extension of majority voting instead of unanimity to a } \\
\text { number of new policy fields }\end{array}$ & passim \\
\hline $\begin{array}{l}\text { Keeping a powerful } \\
\text { and efficient } \\
\text { Commission }\end{array}$ & $\begin{array}{l}\text { Increasing the powers of the President of the Commission } \\
\text { (and possibility to dismiss his colleagues) } \\
\text { Trying to reduce the size of the Commission to } 2 / 3 \text { of the } \\
\text { number of member states }\end{array}$ & I-27 \\
\hline $\begin{array}{l}\text { Giving stability to the } \\
\text { European Council }\end{array}$ & $\begin{array}{l}\text { Creation of a permanent Presidency of the European } \\
\text { Council, instead of the system of half-yearly rotation } \\
\text { between Heads of Government of the member states }\end{array}$ & $\mathrm{I}-22$ \\
\hline $\begin{array}{l}\text { Increasing the } \\
\text { visibility of the EU } \\
\text { institutions }\end{array}$ & $\begin{array}{l}\text { Permanent Presidency of the European Council (2 } 1 / 2 \\
\text { years renewable once) } \\
\text { Minister of Foreign Affairs ( } 5 \text { years renewable) }\end{array}$ & $\mathrm{I}-22$ \\
\hline $\begin{array}{l}\text { Increasing } \\
\text { transparency and } \\
\text { accountability }\end{array}$ & $\begin{array}{l}\text { Replacement of the EU and EC treaties by a single } \\
\text { Constitution for Europe } \\
\text { Clarification of the policy instruments, which become } \\
\text { more similar to those known in national law (European } \\
\text { laws and regulations) } \\
\text { Simplification of the decision making procedure } \\
\text { Involvement of national Parliaments in the decision } \\
\text { making procedure, mainly through better information } \\
\text { mechanisms and possibilities to formally voice their } \\
\text { concerns }\end{array}$ & $\begin{array}{l}\text { Passim } \\
\text { I-33 to I- } \\
39 \\
\text { I-34- to } \\
\text { I-36 } \\
\text { Protocol } \\
n^{\circ} 1\end{array}$ \\
\hline
\end{tabular}

* References to the relevant articles of the Treaty establishing a Constitution for Europe. 
These are new and to a large extent unknown challenges for the EU, which may or may not be relevant to ongoing experiences of regional integration in Latin America and the Caribbean, according to the importance of asymmetries and there comparability to those which exist in Europe. This is why the overview of solutions which are on the agenda of reform in the EU context will only be very briefly described and commented, without trying to assess their appropriateness as solutions in the European context.

The solutions which are pointed at here are only a rather small and to some extent arbitrary selection - derived from the agenda of the European Convention, which drafted the Constitution for Europe. The purpose of this section is mainly to illustrate the growing complexity of European Union governance and the constant search for adaptations, not to give an in-depth analysis of present EU reforms. The possible relevance of each of these innovations should be considered from two points of view: as illustrations of the combination of a solid and steady general architecture with the necessary flexibility to respond to new challenges, and possibly on there own merit, provided they are not taken out of their general context.

Trying to describe what is proposed in Constitution for Europe is easy but might be misleading. The same is true official documents like the European Commission's White Book on Governance of 2000, or of European Council conclusions, like the Lisbon Strategy for instance see 4.2. Behind the technical jargon or fashionable phrases, the realities of European governance would need to be scrutinised in depth before establishing to what extent comparisons of best practices or institutional devices are based on contexts which are too different to allow for the transposition of a given device. This does not mean that none of the solutions proposed in Europe could be interesting for Latin America. However it would be more interesting to examine the processes that have been used or will be used in order to develop and implement those solutions.

In order to present just one example, it is probably far more interesting from a Latin American perspective to understand the project, the whereabouts, and the proper dynamic of the European Convention 2002-2003, and how it interacted with it's political and social environment, than to try and go in any detailed analysis of the institutional innovations which 
have been formulated in the Constitution for Europe. The European Convention has been established by the European Council in December 2001 with a rather ambiguous mandate. Its task was to propose reforms, that would help overcome some general issues identified by the European Council and which are taken up in this section. The Convention was invited to come up with a report that would propose several alternative solutions if needed. The possibility of drafting a 'Constitution' was only mentioned as a vague hypothesis.

The Convention eventually showed much boldness than expected by some governments, in delivering a fully fledged Draft Treaty establishing a Constitution for Europe, designed to replace the existing treaties, instead of a mere series of recommendations. It also showed much realism: it decided to limit the scope of proposed innovations and to avoid changing the distribution of powers between the EC/EU and its member states. None of the existing EC/EU powers was given back to member states, and a very small number of increases of EC/EU powers were only proposed in full agreement with all national governments. This combination of boldness and realism was without any doubt the result of the leading role in the Convention of experienced politicians from several different member states, who had personal experience both in national and European institutions. They made sure that the Convention remained in touch with reality and acknowledged the limits beyond which member states government were not ready to go.

In intergovernmental conferences (IGC) - which traditionally prepare the European integration treaties and their amendments - diplomats and experts of EC law dominate decision making. In sharp contrast, the European Convention was composed of a great majority of experienced parliamentarians, coming both from national parliaments and from the European Parliament. This allowed the Convention to propose a number of changes in the institutional setting, procedures and instruments, which were designed to make the functioning of the EU easier to understand to citizens, who are more accustomed to their national political institutions than to the peculiarities of the institutions based upon the Community method. The Convention had an original composition: two representatives of Parliament and one of the Executive for each country, and in addition a good number of members of the European Parliament and two European Commissioners. It also had original working procedures: intensive use of electronic communication for the submission of proposals specialised working groups, and very tightly 
organised plenary sessions, without any votes: decisions were taken by consensus of all the Convention. These original composition and procedures allowed both to include representatives of thirteen candidate countries in the Convention proceedings without any discrimination against them, while acknowledging the different weights of countries and institutions.

It would be wrong to try and reproduce the Convention method in other regional settings for the sole reason that it managed in 2003 to agree upon reforms which previous IGCs had failed to adopt in 1997 and 2000. IGCs have been quite successful in achieving their aims in 1985 and 1991, but the fact that they may easily be blocked by the resistance of a single government and the quest for more democratic legitimacy and transparency rendered this method inappropriate for further reform in the governance of regional integration.

\subsection{Enhancing co-ordination through alternatives to the Community method}

The continuing expansion of common policy fields and the increased sophistication and consolidation of policy tools which has been the consequence of the consolidation and deepening of integration, reinforced by enlargement, have been showing the limits of the Community method. As opposed to the first decade of integration, where the goal of the Six was to create some sort of 'United States of Europe', and where disagreements related almost only to the priorities and pace of integration, a growing number of member states are now resisting more fundamental changes in European governance which would transform the EU as much as giving it some of the main characteristics of a federal state. They agree however upon the need to further develop EU wide cooperation in a growing number of fields. This has lead to try and find modes of governance which are different from the classical Community method.

During the last decade two of them have attracted growing attention from practitioners and academia in Europe.

\subsubsection{The 'Open Method of Co-ordination'}

The so-called 'Open Method of Co-ordination' ('OMC') has been formalised in the framework of the Lisbon Strategy, adopted by the European Council in the Portuguese capital 
in March $2000^{39}$, with the aim of making the EU the most competitive region in the world within a decade. Five years later this objective does not really seem in reach. This strategy for increased competitiveness was touching upon policy fields where the EC/EU had no formal powers to take action - especially in the field of employment - and where there were too many and too important differences of views about the best policy tools amongst the fifteen governments, divergences that impeded trying to tackle the issue by treaty reform, as had been done with the strategy for the completion of the internal market fifteen years earlier. The 'OMC' was thus presented as an alternative and more flexible way of doing things in common in the EU.

The 'OMC' is based upon the establishment of common objectives - quantified as much as possible, like reducing the level of unemployment for instance - which are agreed upon in the framework of Council meetings. The coordination procedure is based upon the exchange of best practices through reporting mechanisms and peer review. While this seems to depart from the Community method, the European Commission managed to play an important role through proposing the objectives, and organising the procedures for reporting and monitoring peer review. A major difference with the Community method is that the 'OMC' uses only non-binding instruments, sometimes described as soft law, as opposed to the usual treaty provisions and legislation: the ECJ is therefore totally excluded of the 'OMC'.

A number of comments were raising fears that the 'OMC' would be used in order to bypass treaty obligations and the limitations set by the treaties to EU intervention. As a reaction to these criticisms, the European Convention established the principle that the use of the 'OMC' 40 was not allowed when the treaties provided for the possibility of EC/EU actions through binding instruments. But it resisted the temptation to codify the 'OMC'. The 'OMC' is especially difficult to assess in the framework of low-growth of some of the more important economies of the EC. Once the reality behind the label is identified, it may well be that the equivalent of 'OMC' is already practiced in other experiences of regional integration.

\footnotetext{
39 Lisbon Strategy: PRESIDENCY Conclusions - Lisbon European Council - 23 And 24 March 2000, see http://ue.eu.int/ueDocs/cms_Data/docs/pressData/en/ec/00100-r1.en0.htm

40 Art. I-12 Constitution for Europe.
} 


\subsubsection{European Agencies}

During the last decade, a growing number of so-called 'European Agencies ${ }^{41}$ have been set up by Council and Parliament regulations or decisions. This is not a single category of institutions, as they are endowed with different functions, different institutional set-ups, and above all different procedures and different powers. Like in the case of the 'OMC', European Agencies have raised a lot of attention in practice and academia.

The institutions which are usually referred to as European Agencies could be better described as European Regulatory Agencies, as opposed to the European Executive Agencies which are set up in order to manage some specific aspects of the functioning of the European institutions (in the field of training, for instance). European Regulatory Agencies are specific bodies which have been set up in order to coordinate certain regulatory functions in a number of policy fields where specific expertise is needed, like for instance environment or food safety.

Governance by - or with - European Agencies departs from the Community method in a number of ways: the functions which are usually exercised by the Commission are being split up between the latter and the Agency, agencies do not have normative powers, member states administrations and other stakeholders are directly represented in the boards of these agencies, etc. However, European Regulatory agencies remain at arms' length from the European Commission; they are not totally independent bodies.

European Agencies might be easier to assess individually than the 'OMC', although many of them have been set up too recently to enable an interesting assessment; but it is extremely difficult to assess more generally whether they are leading for an in-depth change in European governance, or just for adaptations at the fringe.

Here again, assessing the relevance of both these attempts at reforming the governance in regional integration - or at least to diversify the modes of governance - does not depend on a detailed analysis. What might be of interest is to understand how they represent attempts to depart from the main method of European integration: the questions which cannot yet be answered are whether these attempts will be successes or failures. In the case of the 'OMC', 
furthermore, it is not possible to predict whether it will only be applied during a transitional phase - before applying the Community method to the concerned policy fields -, or whether on the contrary the 'OMC' announces more radical changes in the overall governance of European integration.

\subsection{Differentiating integration according to policy fields}

The 'OMC' and European Agencies do not stand alone as examples of flexibility in governance. They have to be considered in a wider context of differentiation of in European integration, resulting from a kind of competition between the Community method and the intergovernmental method. Three further tools of flexibility have been foreseen or tried out by treaty provisions.

First, a phenomenon of variable geometry for some community policies has developed as a result of the different views between EU governments about what should be further developed together. Beginning with the Maastricht treaty in 1992, some exemptions have been foreseen for states who proved reluctant to join in new developments: the United Kingdom between 1992 and 1997 for the further development of legislation in the social field, the UK and Denmark for the progressive set-up of the European Monetary Union from 1994 onwards, the UK, Ireland and Denmark as regards several different aspects of police-cooperation, etc. Here again it would probably be rather irrelevant for other experiences of regional integration to analyse in detail the scope and characteristics of the concerned policy fields, or the different mechanisms for exemption, so called opting-in clauses or opting-out clauses which have been inserted in different treaties. It would be far more important to insist upon the fact that this variable geometry only affects matters which are not or not yet at the heart of the integration project, at the time where the exemptions are foreseen, and that they always have been accepted by a number of actors only with the hope that they would be only transitional.

Second, as already indicated in earlier sections of this paper, the development of integration in new fields which were considered as sensitive from the point of view of

\begin{tabular}{lll}
\hline 1 See 'The Agencies of the European Community, History, How do they function, \\
69
\end{tabular}


sovereignty - foreign and internal affairs - was not undertaken with the Community method but with specific procedures, although the same institutions were in charge of integration. Here again, the details of the institutional settings of each of the three 'pillars' of the EU, or the way some aspects have been 'communitarised', are probably of little interest to other experiences of regional integration. What should be considered with care is that EU member states have until now felt the need to put the different forms of governance of integration into a common framework, and that most specific arrangements have been or are still considered as transitional, with the exception of foreign affairs and external security.

A third attempt at differentiation in the framework of the treaties is represented by the so called 'enhanced cooperation'. Since the treaty of Amsterdam in of 1997, the EC/EU treaties include complicated mechanisms in order to allow a number of member states to cooperate in some new policy fields although not all EU countries would follow the move. As a matter of fact there had been cases where this had happened before: the most clear-cut was the Schengen agreement in 1985, where five out of ten member states decided to progressively suppress border controls on persons in their mutual relations. The experience was a success: most other member states later joined in the process and with the Amsterdam treaty of 1997 the agreements and regulations which had been reached under the Schengen arrangements where incorporated into the EC Treaty.

As opposed to the Schengen experience, which started between member states but totally outside of the framework of the EEC institutions, the idea of enhanced cooperation is that the countries concerned will insert their cooperation into the EU/EC framework right from the start and that the EU institutions, especially the Commission, will be involved in the development and management of the new policy field. Since the possibility exists in the treaties, there have however not been serious attempts to start any enhanced cooperation. The very strict conditions laid down in the treaties might explain it, or simply the fact that there is no serious will of a number of countries to go along this path. The mechanisms of enhanced cooperation are probably of little interest to regional integration in Latin America and the Caribbean, as they have been designed for a situation where there is already a very solid core field of integration involving all partner countries. What might be more relevant is that practice 
shows that it is paradoxically easier to further develop integration with all partners then with only a group of partners, but for very specific fields where the appropriate method is to reform the treaties with opt-in clauses for the more reluctant countries.

4.4 Addressing the management deficit of the EC/EU system in a context of continuous enlargement and deepening of European integration

Politicians, the press and academia have been extremely quick to take over the formula of the 'democratic deficit' of the EU in order to criticise its institutions and functioning or to set up an agenda for reform. Nothing of the like happened with the concept of "management deficit', which has been coined in public management literature in the early nineteen nineties (Metcalfe, 1992 \& 1994). The early nineties saw a considerable development of policies which imply important financial transfers between member states - like the EC regional development policy, and more recently research and innovation - or to third countries - like development aid and assistance to Eastern European countries after the collapse of communist regimes. With the Treaty of Maastricht of 1992 the EU member states further developed integration in new fields, where the classical EC policy instruments could not simply be left to member states institutions for their implementation. Little was done in order to adapt the internal functioning of the European Commission's administration to these new tasks.

The Commission administration had been mainly designed in the early sixties in order to propose legislation and regulations and to monitor their implementation with the ultimate sanction of court proceedings - with the exception of competition rules where the Commission had the powers of a competition authority right from the beginning. It was skilled to draft legislation and regulations and to interact with national administrations in two main ways. First it was accustomed to convening meetings of committees composed of national representatives who could approve or reject the Commissions proposals for further detailed regulation in those fields - like the common agricultural policy - which needed an important amount of regulation for their functioning. The growth of these committees has been described under the concept of 'comitology' and may be understood as the result of a lack of willingness of national governments to let the Commission play the role of an executive without being overviewed by 
their representatives. It may also be considered as the institutional and procedural expression of a system of governance based on network cooperation. The Commission always plays a central role in the functioning of these committees. Second it had developed its monitoring function over the implementation of common policies along rather formalistic procedures based upon the logic of possible court proceedings in case of infringement.

With the development of new policy tools and fields, the Commission administration, while continuing to exercise the functions it was accustomed to accomplish, had now to allocate funds, to contract with other organisations of the public and the private sectors for the implementation of action programmes, and to foster exchanges of information between national administrations in a multilateral setting rather than in the familiar framework of 'comitology' and possible actions for infringement against member states. While a number of officials and some Commissioners were conscious of the challenge these changes represented, the Council (i.e. the national governments) did not take it into consideration, and only insisted upon the need to carry out the new functions and face enlargement without significant increases in permanent staff or budget.

The management problems of the Commission, due to the mismatch between its growing tasks on one side, and its capacities in terms of human resources, management skills and procedures on the other, have been growing over the nineties, until the crisis that led to the withdrawal of the European Commission chaired by Jacques Santer in 1999. This crisis was due to the Parliament's concern with an accumulation of cases of mismanagement on one side, which were scrutinised by a Committee of independent experts and by the very poor handling of the mad-cow disease crisis by the European Commission. As a result the new Commission chaired by Romano Prodi put management reform and governance very high on its agenda. During the mandate of the Prodi Commission (1999-2004) a number of reforms were undertaken as regards the management of the Commission, with important changes in financial, administrative and staff regulations and a series of training actions amongst others. The Prodi Commission also invested time and energy in the production of a White Book on Governance in the European Union, in the year 2000, which has a number of shortcomings, but was the first attempt to consider the governance issues of integration in a comprehensive manner, taking into account not only the EU institutions but also governments and public 
administrations in the member states, as well as interest representation, non governmental organisations and to a certain extent civil society.

As the various proposals for reform are very recent and are based on contemporary realities - like the development of information technologies - and concepts - like the emergence and consolidation of networks - it could be tempting to focus on the White books and regulations which have been adopted and to draw recommendations for other experiences in regional integration, event though these reforms are not yet implemented for a sufficient time to allow for their assessment. The relevance of any such exercise seems very questionable, as the value of these recommendations and proposals is strictly proportional to their being embedded in the context of EU integration. As a matter of fact, even in the EU context, some of these documents are already outdated as they do not really take into account the challenges of enlargement, especially in view of the new problems of management which are bound to rise due to the number of new member states and the differences in economic and administrative capacities between old and new member states.

The question of the management deficit is however highly relevant to other experiences in regional integration as an issue. The European experience mainly tells how difficult it is to draw the attention of decision makers to these issues, which have to be addressed both at the level of regional institutions and in the member states. In a sense they are far more difficult to resolve than the other issues of regional governance, because they cannot be resolved by treaty reform and institutional design, but need constant renewed attention of all concerned decisionmakers, and a serious effort in the allocation of human resources and the development of skills for the management of policies in differentiated and evolving ways. 


\section{List of Tables}

Table 1: European Communities (EC) and European Union (EU)

Table 2: Enlarging and deepening integration in Europe

Table 3: comparative economic development of EC/EU member states

Table 4: Governance reform in the Constitution for Europe 


\section{Selected Bibliography:}

Alter, K. Establishing the Supremacy of European Law, Oxford University Press, 2001

Anderson, J. J. (ed.), Regional integration and democracy: expanding on the European experience, Lanham, Md: Rowman \& Littlefield, 1999

Armstrong K. and Bulmer S., The Governance of the Single European Market, Manchester University Press, 1998)

Baun, M. J., A wider Europe: the process and politics of European Union enlargement, Lanham, MD: Rowman \& Littlefield, 2000

Bernard, N., Multilevel governance in the European Union, The Hague/New York: Kluwer Law International, 2002

Bomberg, E., Stubb, A. C-G , (eds.) The European Union: how does it work? Oxford University Press, 2003

Cappelletti, M., Seccombe, M., and Weiler, J., Integration Through Law, Berlin: Walter de Gruyter, 1986

Cavanna, H. (ed.), Governance, globalization and the European Union: which Europe for tomorrow?, Dublin: Portland, OR: Four Courts Press, 2002

Chiti, E., Decentralised integration as a new model of joint exercise of community functions?: a legal analysis of European agencies, Oslo : ARENA, 2002

Cremona, M., The enlargement of the European Union, Oxford/New York: Oxford University Press, 2003

Commission of the European Communities, Report from the Commission on European governance, Luxembourg: Office for Official Publications of the EC, 2003, Series $\operatorname{COM}(2002) 705$

de Búrca, G. and Scott, J. Constitutional change in the EU: from uniformity to flexibility?, Oxford: Hart, 2000

de la Porte, C. \& Pochet, P (eds.), Building social Europe through the open method of coordination, Bruxelles/New York : P.I.E.-Peter Lang, 2002

Eriksen, E. O., Joerges, C., Neyer, J., (eds.) European governance, deliberation and the quest for democratisation Oslo: ARENA, 2003

Fröhlich, S., The difficulties of EU governance: what way forward for the EU institutions?, Frankfurt am Main /New York: Peter Lang, 2004 
Gilbert, M., Surpassing realism: the politics of European integration since 1945; Lanham: Mad: Rowman \& Littlefield, c2003

Gual i Sole, J. (ed.), Building a dynamic Europe: the key policy debates, Cambridge (UK) ; New York (NY): Cambridge University Press, 2004

Haas, Ernst B., The Uniting of Europe, London: Stevens \& Sons, 1958

Haas, Ernst B., Beyond the nation-state: functionalism and international organization, Stanford University Press, 1964

Harlow, C., Accountability in the European Union, Oxford: Oxford University Press, 2002

Hayward, J. E. S., Menon, Anand, (eds.) Governing Europe, Oxford/New York: Oxford University Press, 2003

Héritier , A. [et al.], Differential Europe: the European Union impact on national policymaking, Lanham, Md.: Rowman \& Littlefield, 2001

Hooghe, L. and Marks, G., Multi-level governance and European integration Lanham, MD: Rowman \& Littlefield, 2001

Joerges, C., Ladeur, K.-H., Ziller, J. \& Dragomir, L. , Governance in the European Union and the commission white paper, Florence: European University Institute, 2002

Knill, C., The Europeanisation of national administrations: patterns of institutional change and persistence Cambridge /New York: Cambridge University Press, 2001

Kohler-Koch, B., Linking EU and national governance, Oxford: Oxford University Press, 2003

Kramsch, O. T., Hooper, B., (eds.) Cross-border governance in the European Union, London; New York: Routledge, 2004

Magnette, P., Contrôler l'Europe: pouvoirs et responsabilité dans l'Union européenne, Bruxelles: Université de Bruxelles, 2003

Magone, J. M. (ed) Regional institutions and governance in the European Union, Westport, Conn. ; London: Prager, 2003

Metcalfe, L., 'After 1992: Can the Commission Manage Europe?' Australian Journal for Public Administration, v. 51 n. 11, 1992, p. 117-130.

Metcalfe, L., 'International Policy Coordination and Public Management Reform', International Review of Administrative Sciences, v. 60, 1994, p. 271-290

Monnet, J., Memoirs, translated by R. Mayne, London, Collins, 1978.

Olsen, J. P., Reforming European institutions of governance, Oslo: ARENA, 2002 
Pollack, M., The Engines of European Integration: Delegation, Agency and Agenda-Setting in the EU, Oxford Univerity Press, 2003

Tallberg, J., European governance and supranational institutions: making states comply, London/New York: Routledge, 2003

Wallace, W. (ed.), The Dynamics of European Integration, London: Pinter, RIIA, 1990

Weatherill, S., Law and Integration in the European Community, Oxford: Clarendon Press, 1995

Ziller, J., La nouvelle Constitution européenne, Paris: La Découverte, 2ème triage mis-àjour 2005. 